University of Pennsylvania Carey Law School

Penn Law: Legal Scholarship Repository

Faculty Scholarship at Penn Law

2004

\title{
The Virtues of Uncertainty in Law: An Experimental Approach
}

Tom Baker

University of Pennsylvania Carey Law School

Alon Harel

Hebrew University of Jerusalem

Tamar Kugler

Hebrew University of Jerusalem

Follow this and additional works at: https://scholarship.law.upenn.edu/faculty_scholarship

Part of the Criminal Law Commons, Insurance Commons, Insurance Law Commons, Jurisprudence Commons, Legal History Commons, Legal Theory Commons, Other Philosophy Commons, Theory and Philosophy Commons, and the Torts Commons

\section{Repository Citation}

Baker, Tom; Harel, Alon; and Kugler, Tamar, "The Virtues of Uncertainty in Law: An Experimental Approach" (2004). Faculty Scholarship at Penn Law. 701.

https://scholarship.law.upenn.edu/faculty_scholarship/701

This Article is brought to you for free and open access by Penn Law: Legal Scholarship Repository. It has been accepted for inclusion in Faculty Scholarship at Penn Law by an authorized administrator of Penn Law: Legal Scholarship Repository. For more information, please contact PennlawIR@law.upenn.edu. 


\title{
The Virtues of Uncertainty in Law: An Experimental Approach ${ }^{*}$
}

\author{
Tom Baker," Alon Harel" EN Tamar Kugler"
}

1. INTRODUCTION

II. AN EXPERIMENTAL INVESTIGATION OF THE DETFRRENT EFFERTS OF

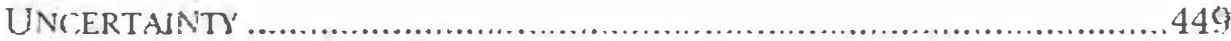

A. THEORE:TCAI. FOUNDATYONS ......................................................449

B. BEHAITORAI. DECISION RHSEEARC:H ON LINTKRTAIATY .......................453

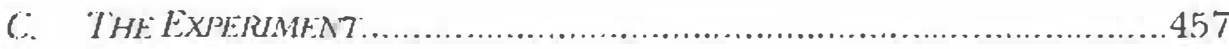

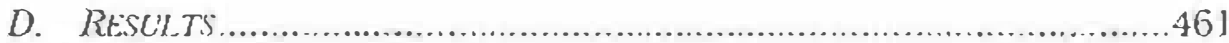

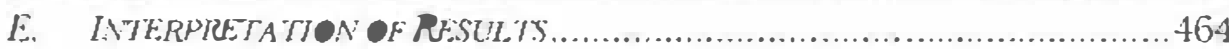

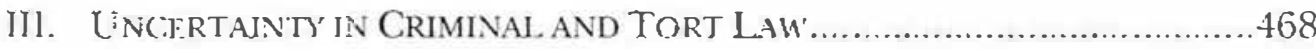

A. UNCERTAINTY IN CRIMINAI I.AH ............................................468

1. Uncertainty Regarding Sanction in Criminal Law .............468

2. Uncertainty Regarding Detection in Criminal Law.............470

3. Manipulating Lncertainty in Criminal Law .........................471

B. LNCERTAINTY TN TORT LAH .............................................4T4

1. Uncertainry Regarding Sanction in Iort Law.................... 174

2. Uncertainty Regarding the Probability of Detection in

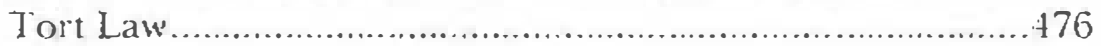

3. Manipulating Uncertainty in Tort L.aw...........................476

* An carlier version of this Article was prestunted at faculty workshops at Albany Law Schuol. Bostun University Law Srlool. Liniversity of Connecticut School of Law, the American Bat Foundarion, the Center for Ethics and the Professions al Ifarvard Lniversity. and hr Cemer for Ralionality at the Hebrew University of Jensalem. Thank you to the participants of thesw workslurss and to Oren Bargill, Michal Barzuza. Bethany Berger, Cany Bomsein, Aar(m Bruhl, Sean Griffith. Assaf Handani, Chrssine folls, Gideon Parchamorskr. Eric Posner. Goorge Prit'st, Edward Rock. Peter Siegelman. Andrew Simsesses, kurt Strasser, Avi Yabach, Dennis Thompson. Avishalom Tor, and bithery Zeiler for theis heipful comments. This rescatch was supponted by the Fulbright program. the Hebrew liniversity of lemulem, the

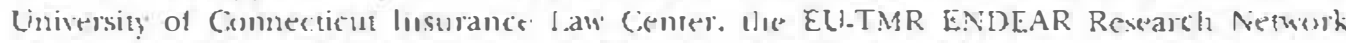

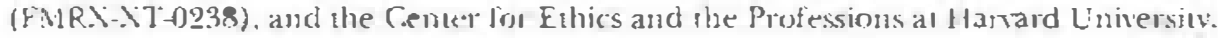

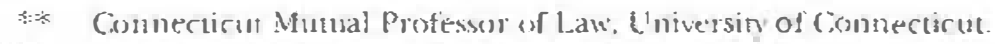

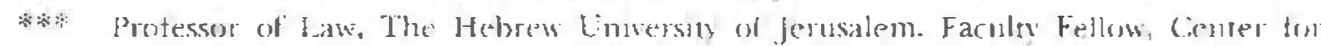
Eahics and the Protessions. Hanard liniversity (2)(y)-1)3).

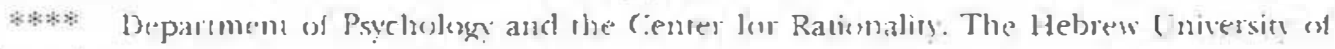
Jerusalem. 
(.. SCMURR

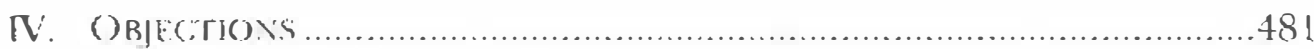

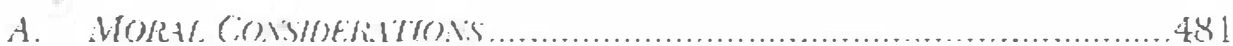

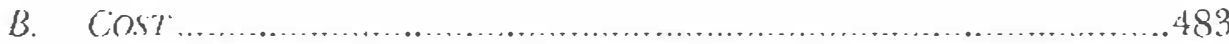

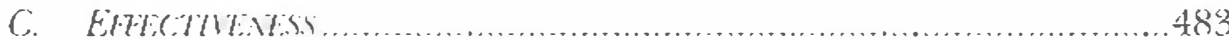

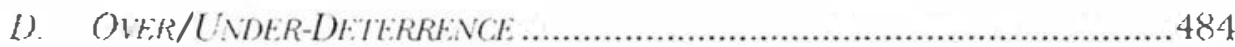

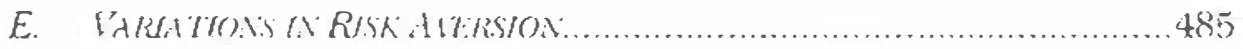

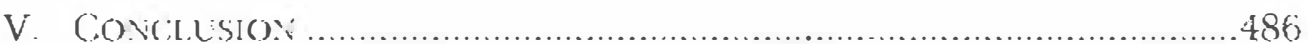

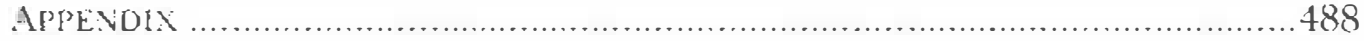




\section{INTRODUC:IION}

Legal scholars generally assume that law shoutd strive cowards coherence.' The ideal of coherence is regarded as particulary importan in the comext of criminal sanctions, where it is argued that "[d] isparity [in semtencing] is a manifest form of injustice, which may bring a sentencing system inco public disrepute." This ideal has had many consequences, ranging from the drafting of the L.S. sentencing guidelines in the 1970\$ 10 the current effort to limit jury discretion over punitive damages in ton law (which is gaining momentum both among scholars and in the comts)."

This Areicle invesigates colherence wilhin an efficiency framework. Using insights from behanional economics and a simple experiment, we conchude that predictability in punishment may be inctficient. In keeping with Bentham's principle of frugality-ihe principle that a sanction should be as small as necessany (o) achieve is goals-we argue that uncerain sanclions may be preferable on efficiency grounds because they achieve more deterrence than certain sanctions of the same expected value. As we acknowledge, this argmment is rwo-edged. On the one hand. it suggests that there may be substantial benefits to uncertainty in sanctioning. ()n the other hand, the setions objections to uncersainty in sanctioning- objections which we acknowledge and explor-also suggest important limits on efficiency as a guide in designing legal rules governing deterrence.

Traditionally understood, legislaters and policy makers hawe mo ways 10 increase the detertence of wongful activity: increasing the size of the sanction imposed or increasing the probability of detection. In combination. these (wo variables constimte the expected sanction. and the experted sanction is whal determines the rate of crime or wrongful bethavion. Some law and economics scholats have poimed out the relevanse of a third variable. attitudes toward risk, explaining that the refervent effect of a sanction depends on the subjective value of the sanction to the individual in question." This subjertive value depends not only on the size and probability

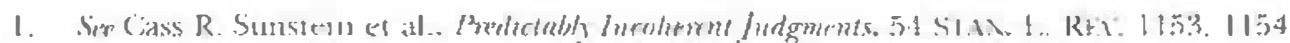
(20)(0)

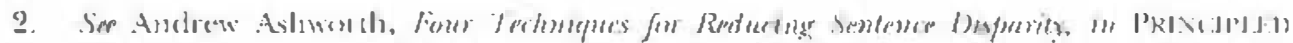

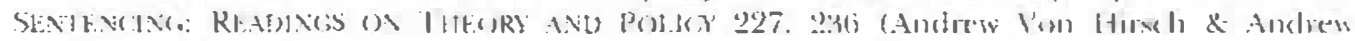
Astworill seds., | (8y9).

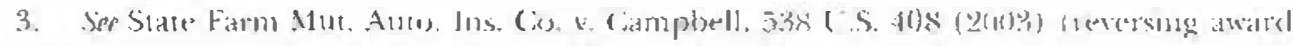

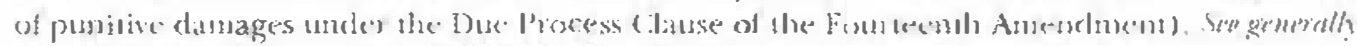

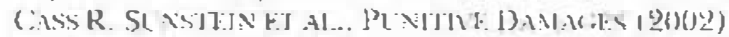

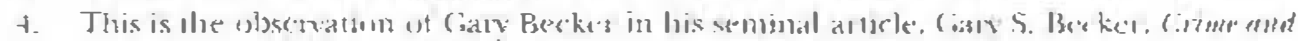

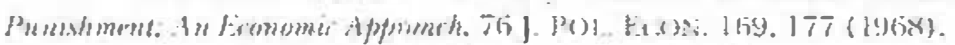

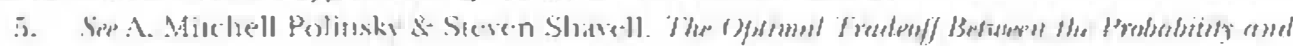

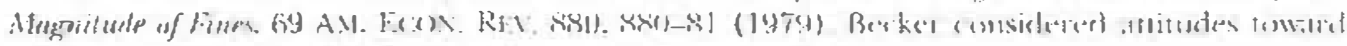

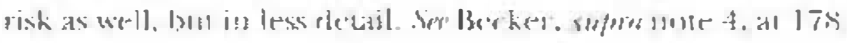


(if a sanctiont. but also on an indisidual's atersion to risk and discount rate: (i.e.. the relative value assigned to instial and subsequent sanction units)."

Wic extend this attention to risk aversion by incorporating insights trom behavional analysis regarding the effect of uncertainty in decision-making. We learn from and extend the results obtained in research on taxpayer compliance' to begin to develop a more general understanding of the role of uncertainty in cletering violations of legal norms.

Parl II of this Article reports the results of a decision-making experinent that explored how uncertaintw regarding the size of a fine and uncertainty regarding the probability of cletection affect the choice to violate a $n 0 \mathrm{rm}$. In the experiment, participants were asked to decide whether w take an action that would result in a monetary payoff but would expose them to a risk of being caught and required (o) pay a tine. The participants were giren real money and assessed real fines, in amounts that varied according to their decisions. Over the course of the experiment. we varied the certainty of the information provided to the participants about the size of the fine and the chances of being caught, while holding constant the expected value of the sanction and the average probability of being caught. In general, the greater the mncertainty regarding the size of the fine or the chance of being caught. the more unlikely participants were to take the action. This result is not an ubvious one. Indeed, one of us predicted on the basis of existing literature (n) uncertainty that individuals would prefer uncertain sanctions to cortain sanctions." Hence, after clescribing these results. Part II reconciles the se results with prior behavioral decision research.

While certainly preliminary and exploratory, the experiment advanced the ven limited prior behavional decision research on compliance with nroms in lwo ways: by framing the decision in a manner that allows the results 10 be generalized to a wider array of situations and by using monetany resards and punishments to make the decision more realistic. Although any conclusions drawn from this research must be quite tentative, the rosults

1. Sie Polinsky \& Shavell, supra nose 5. all sist-81; see atso A. Mitchell Polinsky \& Steven

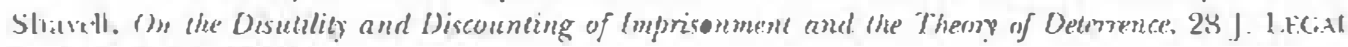
stili. 1. 1-1:3 (1999)

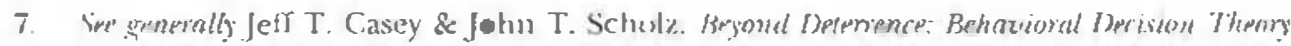

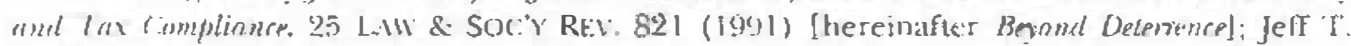

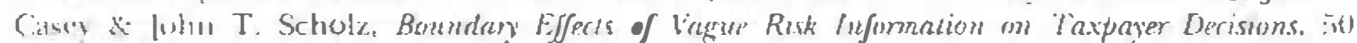

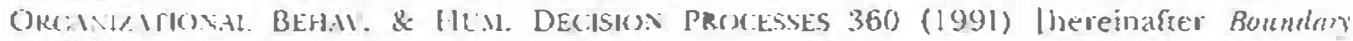

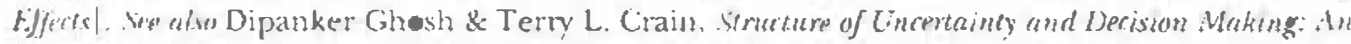
Expremental lnzstigation. 24 DFcisios Sc. 789. 790 (1993): Michatel W. Spicer \& J. Everett

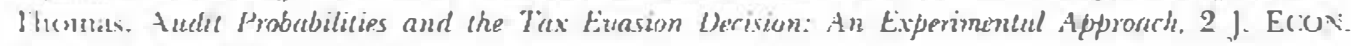

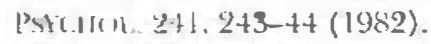

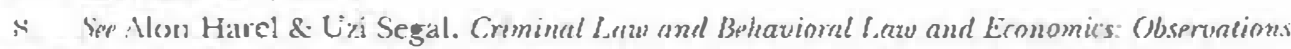

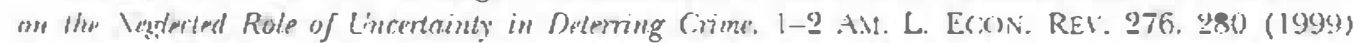

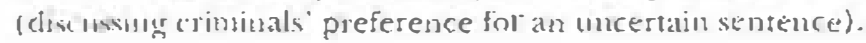


suggest that uncertains with regard to either the size of the sanction or the probability of detection increases deccrence, ceteris paribus.

With regard to criminal law, research of this sort may provide a reason to question the deterrent value of determinate sentencing. With regard to tort law, such research suggests for example that tort reform efforts aimed at making non-economic and punitive damages more predictable may decrease the deterrent effect of tort law (even if the average size of the damages was to remain constant). In both fields, this research suggests that policymakers may be able 10 increase deterrence by manipulating the uncertainty regarding probability of detection. Examples of policies directed at uncertainty in detection include publicizing short-tem, intensive, random stops for drumk driving, random audits for securities fraud, or periodic, intensive review of patient records for medical malpractice. As we will explain, it is this finding regarding the deterrence value of uncertainty with respect to the probability of detection that is most inconsistent with traditional expected mility analysis (and, thus, demonstrates most persuasively the "value added" of a behavioral approach)."

Part 1II of this Article explores the treatment of uncertainty in criminal and tort law. We begin by pointing out that the legal system does not consistently pursue predictability in sanctioning. Consider the following two hypothetical situations. In the first situation, wo individuals commit identical wrongs aud bouh are caught. The first is assessed a fine or damages of $\$ 10.000$, while the second is assessed a fine or damages of $\$ 5000$. If the disparity between these two individuals is due only to chance (for example, a sentencing lotten conducted after the two csiminals were caught), it provides cause for concern. The person who received the harsher sanction has a legitimate moral, and perhaps even legal, complaint: "W7y was 1 punished more harshly than she was?"

In the second situation. ww individuals commit identical wongs but face different probabilities of detection. The difference in the probability of detection follows from a policy, endorsed by police officers, of thoroughly investigating $50 \%$ of the reported crimes (chosen randomly), while conducting only a cursory investigation of the other half. As a result of this "detection lotten." the lirst individual has a $10 \%$ chance of being caught

9 Ser ingra texl acrompanving noles 59-61.

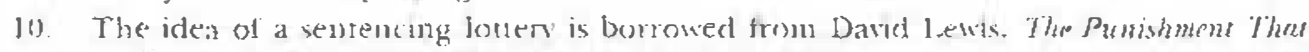

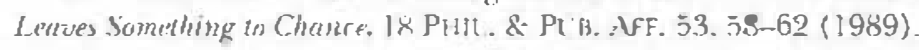

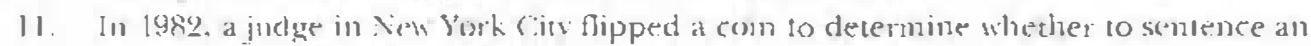

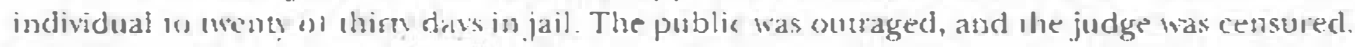

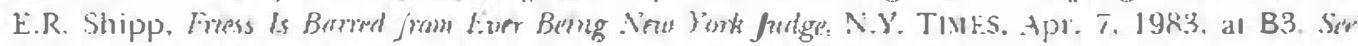

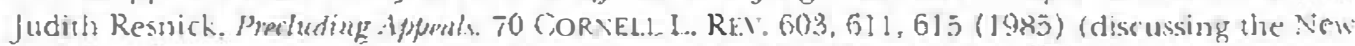
York incident and describung coin flipping as an ineffertive loul for judicial clecisırn making

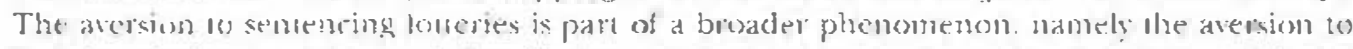

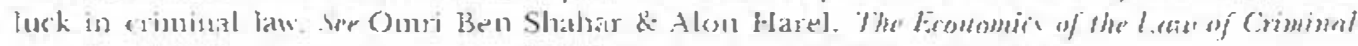

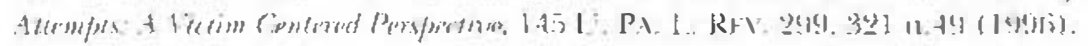




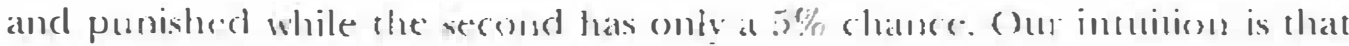
the disparte in the likefihosed of detection betwern the mos miminats does not raise the sane moral resentment as the disparits in the size of the sanction. The monal concton of the person who asks. "Why me?" seems compelling in the case of a sentencing fottem, but not in the case of a detection lottery:" A mumber of well-established legal cloctrines and institusional practices in both the criminal and tort fields reflect shese differences in moral intuition. $1:$ :

After describing some of these doctrines and practices. Part III goes on to explore how criminal law and tort law treat uncertatuty. as well as ways in which uncertatuty can be manipulated-without violating foundational cloctrinal principles-even in contexts in which it is perceived as undesiable. Examples of doctrines and institutional practices that create uncertainty in the criminal law field inclucte prosecutorial discretion to charge crimes up or clowin, sanctions that van accurding to the results of the crime, and the Pinkerton rule (pursuamt (o) which members of conspiracies are liable for the acts of others). Examples in the tort law field include the practice of setting clamages according to the ham to the vicsim, the "randemizing" effect of relying on privatc partic's so enforce the law, and the: ability of liability insurance to reduce (n) manify the uncertainty in tort sanctions. These examples are in adclition to the ren substantial cliscretion granted to criminal and civil enforcencut bodies regarding the allocation of resources to the detection and prosecution of criminal and civil wrongs.

Part IV of this Article addresses a number of important potential objections to manipulating uncertaints to optimize deterrence. Wic examine objections based on momality, cost, effectivensess. and the potential risks of over- and under-deterrence, in addition to (r)jections based on research showing that uncertainty has differential effects on people according to their aversion to risk. While all of these objections raisc important qualifications that may limit the practical application of out analysis in certatin situations, none fundamentally undercuts our project. Indeed, even if all of the objections werc othenvise insurmountable: our rescarch would nevertheless suggest that policy makers could accomplish greater deterrence by focusing public attention on already cxisting and highlw uncertain aspects of civil and criminal sanceioning.

The primaty purpose of this Arricie is not to estatblish, once and for all, that increasing uncertainty with respert to the size of the sanction and the probability of detection is desirable, or tren the more modest goal that increasing uncertainty is necessarily desinable from an efficiency-based perspective. Instead, our aim is to expand the traditional paradigm beyond

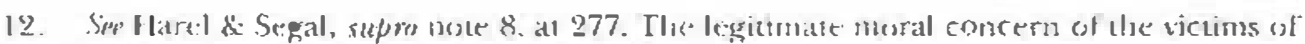
the ivo erintes. honiever, seems likely ou be quite dilferent.

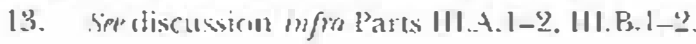


the focus on the size of the sanction and the probability of detection as the means by which law can deter wongful behavior. There is an additional important tool at the disposal of policy makers and legistators: the power to manipulate the certainty of the size of sanctions and the certainty of the probability of their imposition.

\section{AN EXPERINENTAL LNAESTIGATION OF THE DETERRENT EFYECTS OF UNCERTAINTY}

This part describes and presents the results of an experiment conducted in order to investigate the effects of uncertainty. Section A provides the theoretical foundations for the experiment, explaining the differemt meanings of moncertainty and the ways in which manipulating uncertainty could promote deterence. Section B sketches in more detail the purposes of the experiment as well as its limitations. Section $C$ describes the experiment itself. Section D presents the results.

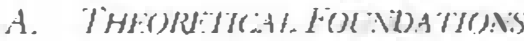

Within an efficiency framework. individuals comply wilh legal norms based on an evaluation, implicit or othentise, of the costs and benefits of compliance. One of the benefits of compliance with legal norms is avoiding the legal sanctions that follow from violation of those norms. Hence, actors make at least an implicil judgment regarding (a) the probability that normviolating behavior will be detected and (b) the nature (or the size) of the sancion that will be imposed in the crem of detection. Because even the best informed, utility maximizing actor is unlikely to have precise information alsout either the probahility of detection or the size of the sanction, such judgments anc neressarily made under conditions of uncertainty. Accordingly, a realistic arcount of the deterrent effect of legal norms should address the elfect of mencerainty both with respect to the nature and size of legal sanctions and with respect to the probability of detection on decision-making. ${ }^{\text {t. }}$

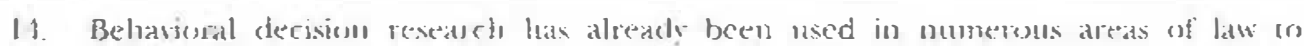

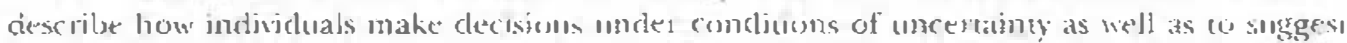

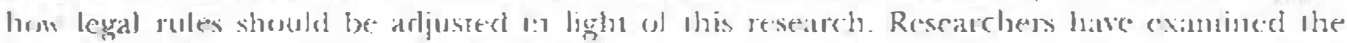

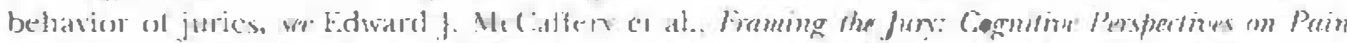

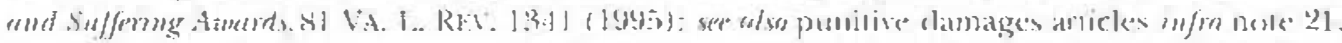

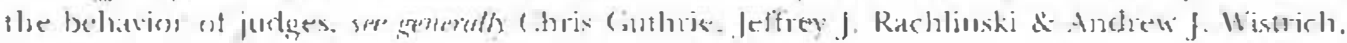

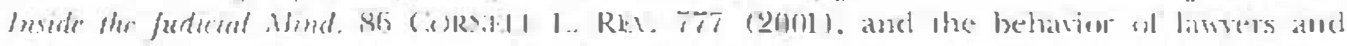

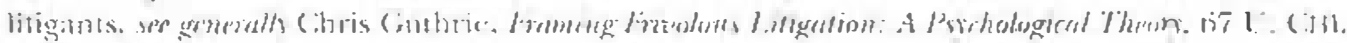

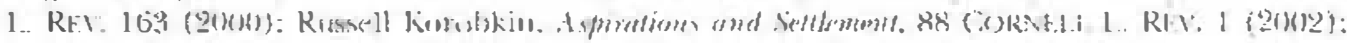

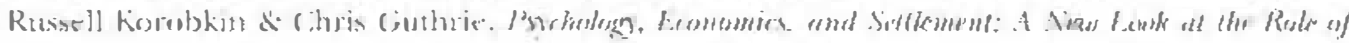

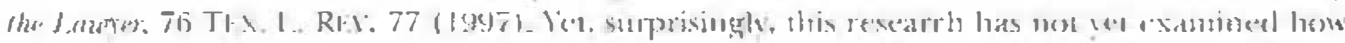

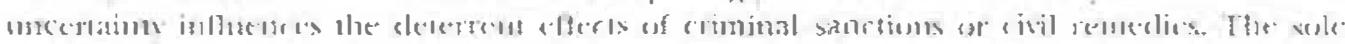

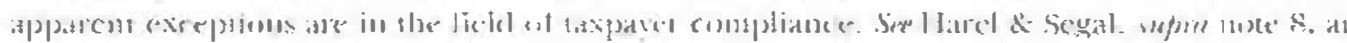

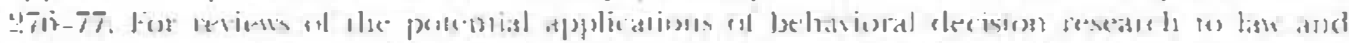

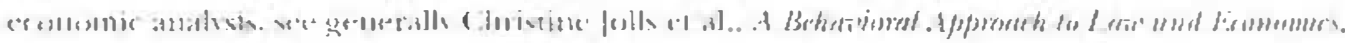


What it means for the res of a sancrion w be more or less certain is intuitively clear and, thus, needs litule cxplanation. A fixed fine fir a given wrong is more certain than a fine in an amoum that depends on the flip of a fair com. Similarly, a fine in an amount based on the flip of a fair coin is more certain than a fine in an amount that depends on one or more factors that are less predictable than the flip of at fair coin. such as a fine that clepends on the temperature next week.

Certainty in cletection is more complicated. In this regard we need to make a crucial distinction between she prebahility of detertion and the precision with which individuals are able io know the probabilisy of detecrion. In everyday speech. the concept of certainty in detection could ref er to both. For example, it would be entirely reasonable to say that one kind of crime. which is $50 \%$ more likely to be detected than another, is more contain to be cletecred.

This "probability of cletection" aspect of certainty, however, is not what concerns us here. Instead, we are investigating the cleterrent effect of varying information about the precision of the probability of cletection. In order not to confound the effects of "likelihood" and "precision," our experiment hoids constant the overall probability of detection (at least insofar as that is possible). The experiment varies, however, the precision with which participants are able to know the probability of cletection. For example, the experiment compares clecisions in situations in which there is a defined risk of $30 \%$ of being fined to decisions in situarions in which there are equal chances that the probability of being fined will be either $20 \%$ or $40 \%$. Similarly, the experiment compares clecisions in situations in which there is a defined risk of $30 \%$ of being fined to decisions in situations in which the probability of being fined is either $20 \%$ or $40 \%$ and there is no information regarding the chances of the probability being one or the other. The situations in which the probability of being fined can be either $20 \%$ or $40 \%$ involve grearer uncertainty (in the sense that interests us here) than the situation in which the probability is a clefinite $30 \%$. $^{1: 5}$

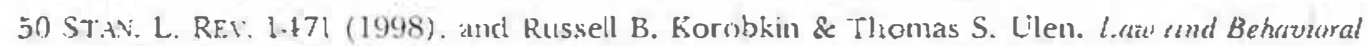

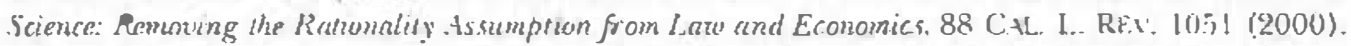

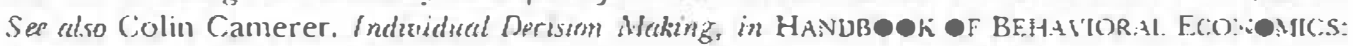
BEHAITORH. DECISION M.thinc; 5KT-676 (Stanley Kaish et al. eds., 1991) (reviewing behavional decision research); David (:ohen and Jack L. Knetsch, Judiczal Choice and Dispanties Between Measures of Economic Vahes, 30) OS6:OODE H.ALL L.J. 737 (1992) (using behavioral decision research findings to explain a variew of common law doctrines).

15. From the perspective uf expected utility theory, the distinction drawn here may seem peculiar. Harel and Segal explain:

Expected utility theon does nut distinguish between lotteries and compound locteries (lotteries in which ihe outcomes themselves are lotteries). For example: if a person believes that therc is an equal chance that the enforcement probability detection is $5 \%$ and $15 \%$. then effectively she believes that the probubility of detection is $10 \%(10.5 \times 5 \%+(1.5 \times 15 \%)$. 
Some prior research in law and economics has begun to explore the possibilir! that risk and uncertainty may be hamessed to enlance deterrence. For example, some torts theorists have raised the possibility that uncertainty could produce over-deterrence. ${ }^{\text {thi }}$ Others have pointed out that attitudes cowards risk are relevant to understanding the deterrent effects of increasing the probability of detection as compared to increasing the size of a sanction. ' Yet, more complex forms of uncertainty such as the concept of sentencing lotteries, detection botteries, or even the relevance of ambiguity (i.e. uncertainty about the relative risk) ${ }^{\text {in }}$ as a tool to increase deterrence. have not been investigated either theoretically or empirically outside the field of taxpaver compliance. ${ }^{\text {to }}$

Two areas in which this omission seems quite striking are deteminate sentencing in criminal law and punitive damages in tort law. During the

Harel \& Segal, sufma unce 8, at 303-04. But the literature on ambiguity suggests that very of 1 en decision-makers do nol treat uncertain probabilities in the way the treat known probabilities. See id.

16. (\% Jwhn E. Callee \& Richard Craswell. Some Lfferd of linentanty un Compliancezvith Legul Standards, T) ('1. 1., R1:. 96.5. 965 (1984) (arguing that uncertainm (Jver it:gal standards will

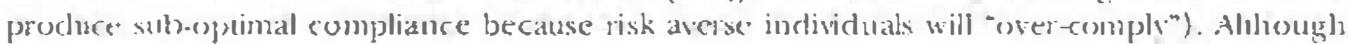

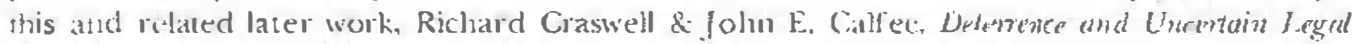

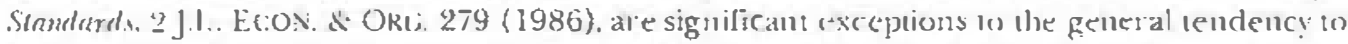
ignese mocediainev, the uncertainty addessed is that wh the content or the legal standard in

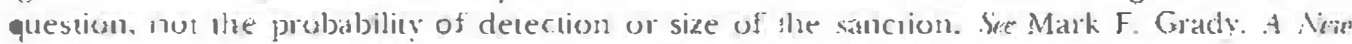

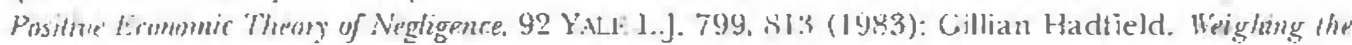

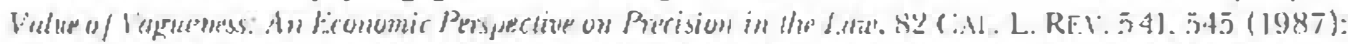

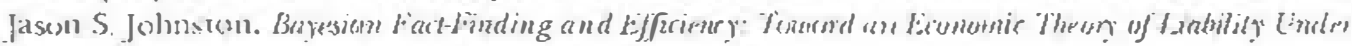

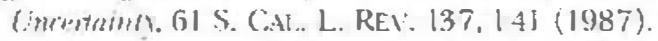

17. Siesufora noncs 5-6.

18. Anbignity represents the dack of confidence. on lack of reliability of the inlormanim one has concerning the relative likelihood of events. Jf a person knews that the te are fifn blact balks and fif whito balls 11 an urn. a person hows thar the probabiling that a white ball be picked up at random is j0\%. If a person knows that dicre are 100 balls some of which are whise whike orliess ane black. a person laces ambiguin-ambiguny which is founded on ignomanse with respect of the relevam probabilities. The clissical expermem suggested b: Eldsberg illusuates ule conceps of ambiguitv. Suppose an un contains ninety balls. thint of which are known (1) be vellow, while each of the uher sixt is known to be either bluc or red, but we exact composition of these sixiy balls is tmknown. In cach ost the next fou loneries. one ball will be preked at random. and the decision maker will be paid accorcling in its color. The Ionts

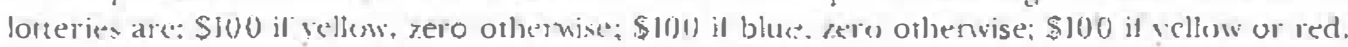

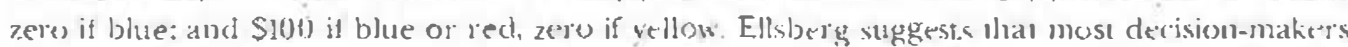

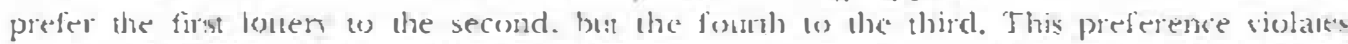

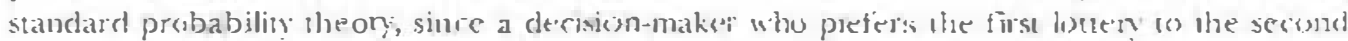

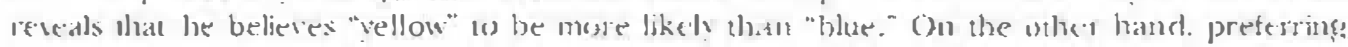

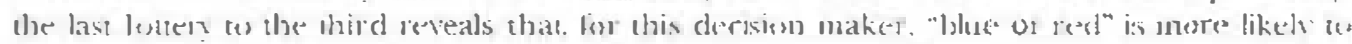

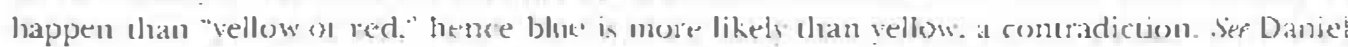

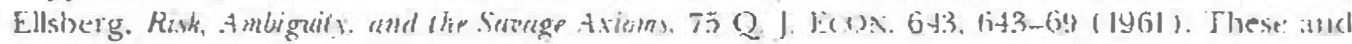

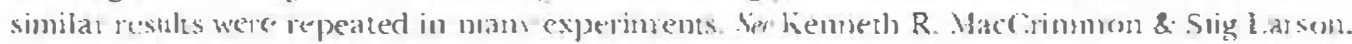

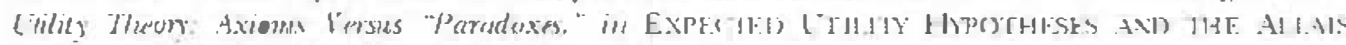

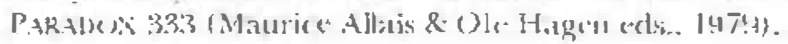

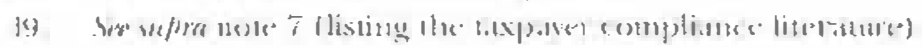




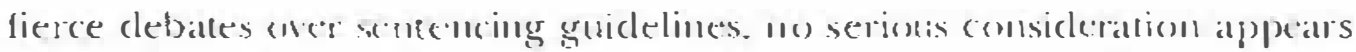

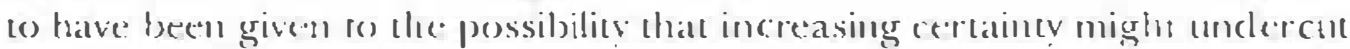
detertence. White this omission mav be understanclatsle. given that the sentencing guiclefines clebate was conducted in moral rather than economic rerms. the comesponding omsission in cliscussions of punitive clamages is more difficule os explain. ()uite secent studies on puntive clamages, some of which explicitl incorporate developments in behawional decision researds. assume without questioning that uncertatuts in sallorous is unclesiable." This assumption is especially troubling because the researchers use their tinclings regarcling the unceranty of jury clecision making (o) argue for legal setorms limiting jus cliscretion. Yet, the mote foundational cuestion, whether moncortanty is indeed undesirable (at least within the efficiencybased framework in which the research is couclucted). typically is cliscussed only summarily in an inteoductory paragraph-a paragraph which recitcrates the conviction that uncertainty with respert to the size of punitive clamages is both unjust and inefficient.

Efficiency consiclesations suggest that cleterrence should be maximized for a given level of expenses. After all. the goil of cleterrence is harm

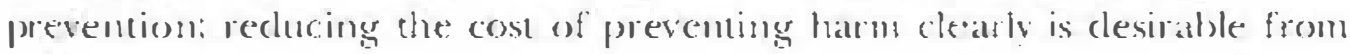

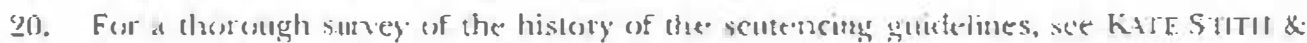

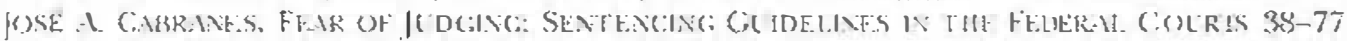

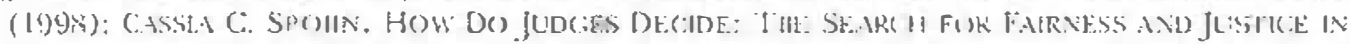

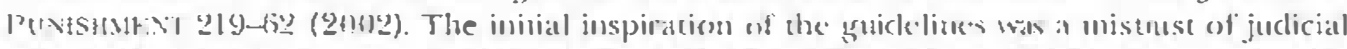
cliscretion. Al a baser stage the sentencing bill fohe bill which estahlishes the sentencing guidelincs) became "tougher" un crime and its "toughtess" was atso justificel in terms of

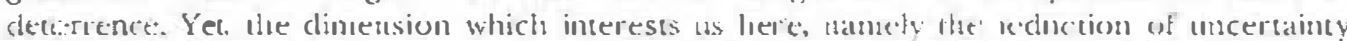
and clisparits, appears to hase been justified exclusively in terms ol pustice rather than in terms of cleserrence.

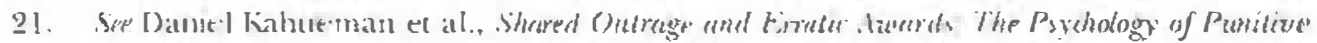

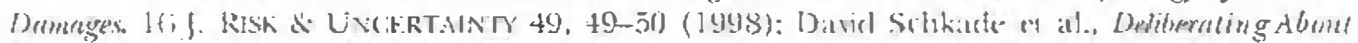

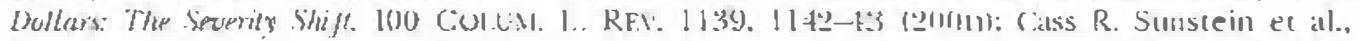

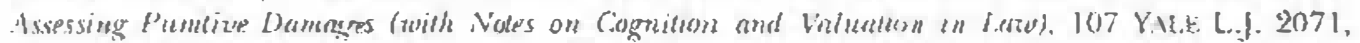

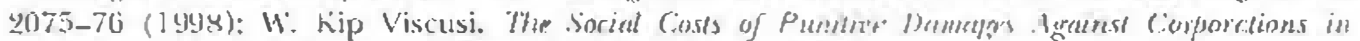

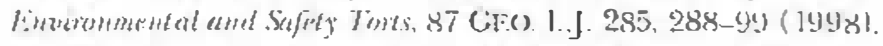

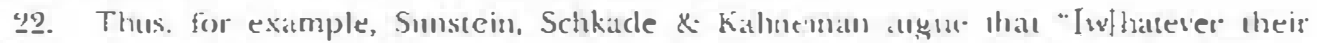
ulumate purpose:s. the nust widespread concern abotil puniuse damiges has been thal they are

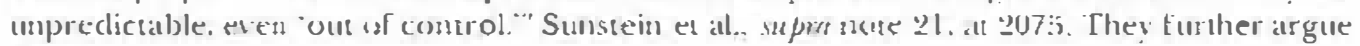
thatt:

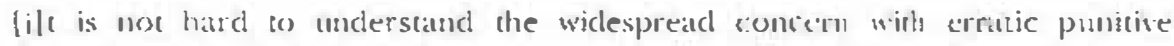

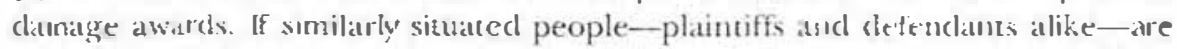

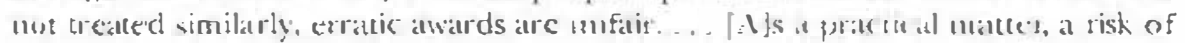

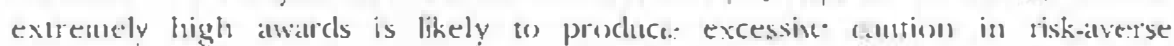
mallagers and gompanies. Hence unpredictable awards create buth unfamess and

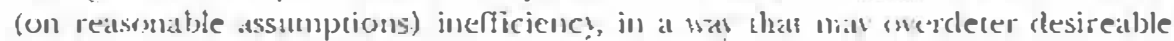
sc lit its:

See id. al $2075-77$. (Mn the other hand, Viscusi angues that "punitive dambeges hatse ne significant

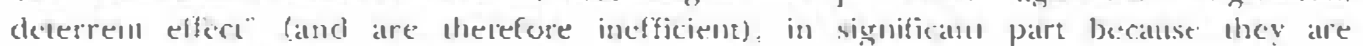

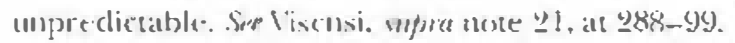


an efficiency perspective. If uncertamy enlances the dererrem effect of a given set of legal rules ancl enforcement procedures. it may be possible to reduce the expected sancions. without decreasing is deterrem effects, by increasing the uncestainn. Lncortainty could be used (o implement the principle of parsimony-the principle that sanctions should be as small as possible. "': For example. if individuals are risk averse to punishmem lonteries, then greater deterrence conld be obtained for the same sanctions, or alternatively the same level of deterrence could be oblained from smaller sanclions.

This consideration serms evident in criminal law. Imposing sanctions in criminal law is expensive. If the average lengel of imprisomment can be reduced, this may save (ossis that would othemise be incured by the state. These costs include the costs of maintaining prisons as well as the costs involved in dismuping papple s lives (both hose in prison and those outside who depend on them). In addition, if the average size of fines can be reduced, this would lower the risk bearing costs of people porentially subject to the fine." Alcematively, if the aremage detection rase can be lowered. there will be savings in enlorcement costs. Similar considerations also apply to torl law. In the standard law and economic account, the primary purjose of ron damages is deterrence." If uncertainty serves as a "force multiplier." then a smaller mumber of wort achions can provide the same deterrent etfect as a larger number of more cerlain acrions, at a lower combined cost. Indeed, it may be that the widely condemuce "forrey" aspects of tort bitigation endorcensen increase the deterrent effects of a tom law regme characterized by rampans under-enforcement. ${ }^{26}$

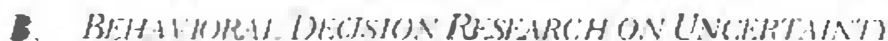

Prior behavional decision research suggests wat uncertainty has predictable effects an decision-making, depending on the way hat a choice is framed. For example. research participants in a wide variety of seltings lend to be risk averse wh respect 10 gains and risk seeking with respect to losses. Faced will a chose betreen a certain gain. say $\$ 5$, and a $25 \%$ chance to get four limes that amoum, more subjects prefer (1) tate $\$ 5$ despite the fact that the expected value of both oplions is exacty the same. Comversely.

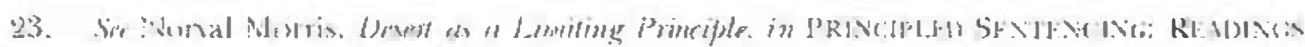

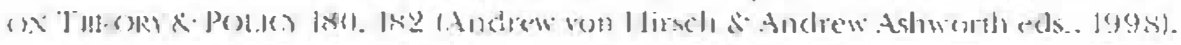

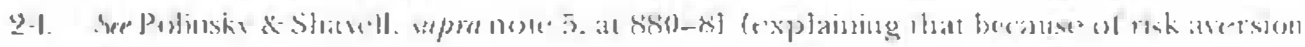

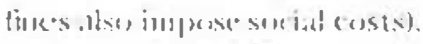

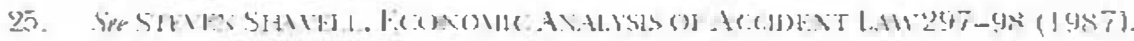

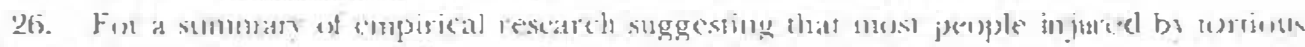

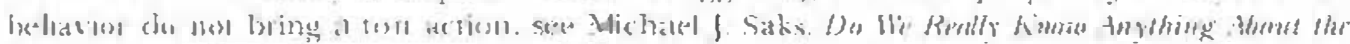

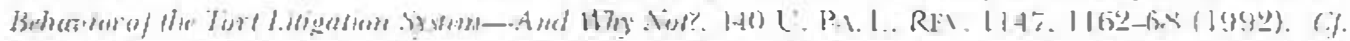

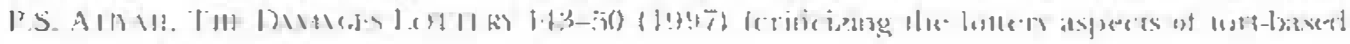

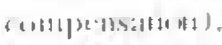




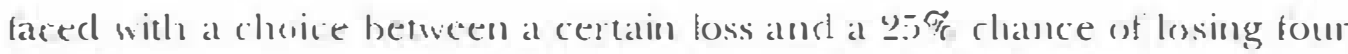
rimes that amount. more suhjects prefer to takt their chances. once again clespite the fact that the expected value of both options is exactiy the same. Behavioral clecision researchers refer to this phenomenon as the reflection effect or the gain/loss framing effect, and they explain this eff ect in terms of loss ancrsion." People are so averse to actually incurring a loss that they are willing to risk a larger loss in order to avesid a certain smaller loss. "." In other words, when all the options present the possibility of loss, loss aversion leads ro a taste for risk.

Two main findings from behaviosal decision research guided our experimental design. First, both uncertainty in probability and uncertainty in outcome have simitar, predictable effects on decision-making (along the lines of the reflection ef fect discussed above. i.c. risk arcrsion with gains, rist seeking with respect to losses, and subject to bulumdiny effects). " Second. within a given range of probabilities or outcomes, inclivicluals are "ambiguity averse" meaning that they clislike uncertain choices more intensely when they do not know the odds of the outcome at anv given point in the range."

Our experiment tests these findings in the context of uncertainty regarding the consequences of a violation of a legat norm. The experiment examines the preferences of participants regarding two aspects of uncertainty: uncertainty in the probability of detection and uncertainty in the size of the sanction. With respect to the size of the sanction, the experiment tests participants preferences under thee different conditions: certainty (in which the sanction is fixed), risk (in which there are two equally possible sanctions) and uncertainty (in which there ase two possible

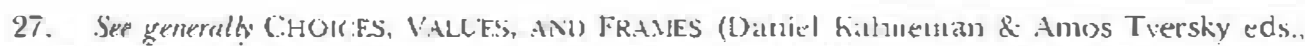
qu(0)) (collecting leading essays growing out of Tiersky and hithematr's research on prospect theory): Daniel Kahneman \& Amos Tversky. Prosped Theon: An Analysis of Derision Linder Risk, t7

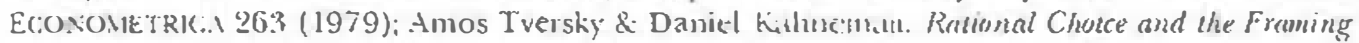

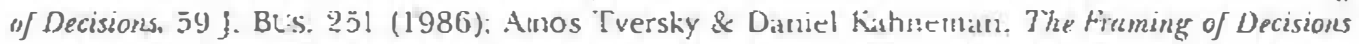

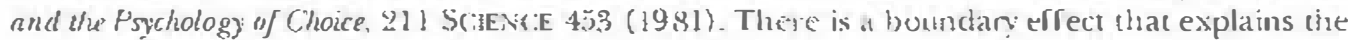
appeal urlecteries and slox machines, however. Subjerts apent w be risk-secking when there is a small possibility of a very large gain. Conversely. subjers appear to be risk-avoicling when there is a small probability of a ver large luss. This later phememenon may help to explatin what may seem to be isordinate public concern about kw frefucous high clamage events such

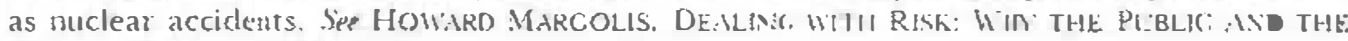
EXPIRTS DISAC:REE 1333 (1996).

28. See Amus Tiversky \& Daniel Kalmeman. loss Arorsum in Riskless Choice: A RrferenreDependent Wodel. 106 2.J. Ecom. 1039, 1040 (1991) freviening previums Lindings regarding loss aversion in risky choices and extending theory to accuunt for iusiversion in riskless choices).

29. See Darid V. Budescu et al., Wudeling Cemanu, tiquinntentsi for Imprerise (iambles. 88

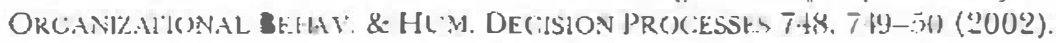

30. See Ellsbers, suprn note 18, at 649-69; Matc crimmun \& Latson, supro note 18, at 369-

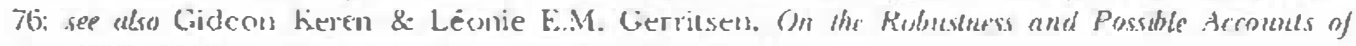

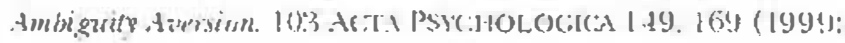


sanctions but no information about their relative likelihood). "With respect to the probability of detection, the experiment tests participants' preferences under three corresponding conditions: certain probability (in which the probability of detection is a fixed percentage), risky probability (in which there are (wo) possible probabilities of detection, the relative likelihood of which is known). and uncertain probability (in which there are two possible probabilities of detection bu no information about their relative likelihood). ${ }^{\text {s? }}$

For ease of cliscussion. we call these three conditions "certain," "risky," and "uncertain" when referring io both the sizc of sanction and the probability of detection. A cerain sanction is therefore a fine of $X$ dolfars. $A$ risky sanction is a fine of cinher Y or ' $Z$ dollars when the probability of $Y$ ' and $\%$ are known, for example. when they depend on the outcome of tossing a fair coin. An uncertain sanction is a fine of either $Y$ or $Z$ when the probabilities are unknown. Similarly, the probability of detection is certain when it is $\mathrm{X} \%$. The probability is risky when it is either $\mathrm{Y} \%$ or $\mathrm{Z} \%$ and the probability that it is either $Y \%$ or $Z \%$ is known. for example, when the probability depends on the restalts of tossing a fair coin. The probability of detection is uncertain when it is either $\mathrm{Y} \%$ or $\mathrm{Z} \%$ and the probability that it is $\mathrm{Y}^{\prime} \%$ or $\mathrm{Z} \%$ is unknown. The combinations resulting from these conditions can be represented in table form. Each box in Table $A$ represents a different combination of experimental conditions. For example, box if represents the case in which the sanction is risky and the probability of detection is certain. The boxes are numbered so that we can refer to the combinations later in the Article.

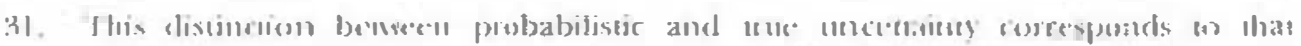

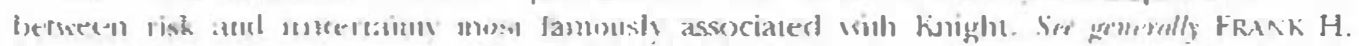

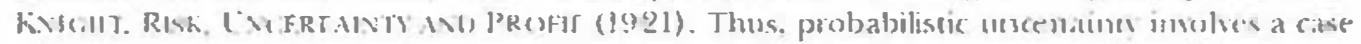

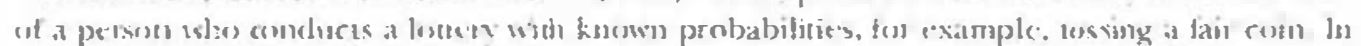

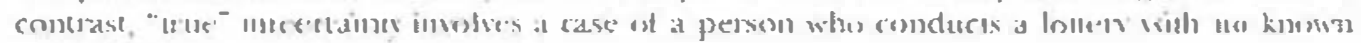
probabililices.

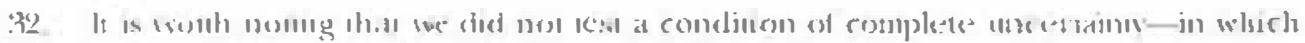

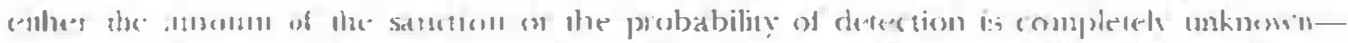

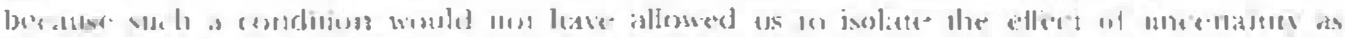

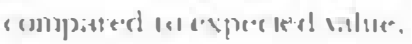


IDASLE A

\begin{tabular}{|c|c|c|c|}
\hline & \multicolumn{3}{|c|}{ SHF (OF SANC:TION } \\
\hline L.IhEIItI (x)[)()\& DETE( TION & CERTAIN & Riskit & LNCERTAIN \\
\hline CERTAIV PR()R:IBIIIIT & 1 & 4 & 7 \\
\hline RISLI PR(BABLIII & 2 & 5 & 8 \\
\hline CACERIAIN: PRC)B.IBIIITY & 3 & 6 & () \\
\hline
\end{tabular}

There are a fow preliminam obsematuons to be made with respect to this catsle and its applicability ourside the laboratory. Fins, certainty or uncertanty refers 10 the subjective comictions of individuals. $A$ sanction is certain if the potential criminal or tortfeasor belieres she or he knows its mannitude. Second, different individuals have different information and therefore the control of the legal system over the certainty or uncertanty of the refevant parameters is limiced. Sometimes, the very same scheme of rules will appear more certain to some actors than others. For instance, it is likely that the same rules may be secn as falling within our "certain" or "risky" cells by more cxperienced offenders while they will be seen as falling within our "uncertain" cells by less experienced offenders. Third, as this suggests. each box in the table represents an idealization that is not fully realiable in the contex of a modern legal system. Nthough a legal system may adopt rules or practices that influcnce the degtce of certanty regarding sanction of the probability of clecection, the manipulability of certanty is limited. Finally, the reatment of uncertanty is likely o depend in practice on an almost intinte and diverse set of factors. including contextual factors that cammot always be examined experimentally. For example, people may treat uncertaiuty differenty depending on whether it involves small or high probabilities s. $^{3.3}$ whether it involies fines or imprisonment." Uncertanty maly also depend on their subjective understandings of the legitimacy of the legal norm in question ${ }^{35}$ or the existence of exual-legal sanctions such as shame:

As a result of these and other limitanions on this kind of research, there are difficulties in classifying neatl "real world" simations into these

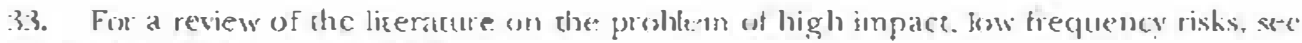
yine:rally Wikciols.s. supra note 27.

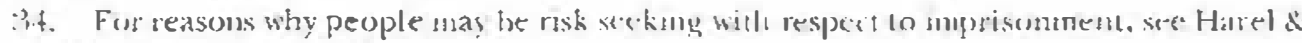
Segall. wernanote 8. at $295-917$.

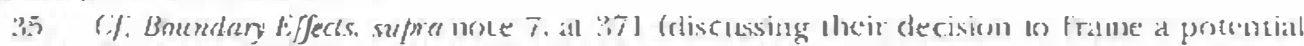

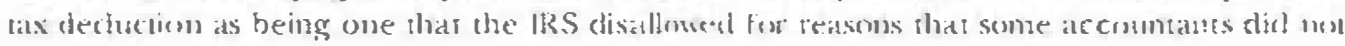
ayce with). 
somewhat idealized ninc combinations and, comersely, in creating roalistic sicuations in the laboratory. Nevertheless. the experimental approach has great advantages in that it allows for the isolation of relevant variahles in ways that are not possible outsirle of the laboratory.

\section{(. THF LXPERMIENT}

Participans and Inesign: Forn-four undergraduate students from The Hebrew University of Jerusalem participared in the experiment. The participants were recruted through a campus advertisement promising a monetany reward for participaring in a decision making task. The design was a "within subject" design, so that carh of the subjects participated in all the experimental conditions.

Procedure: Upon atrival to the laboralory, the subjects were seatred in from of a personal monitor and given instructions concerning the task. All questions concerning the cxperiment were ansivered and insuructions wore repeated until the participants indicated that they fully understood the instructions.

The experiment was fully computerized. During the instructions. the participants learned that they would be asked to make decisions in mentyseven rounds of the experiment. and that they would be paicl on the basis of their decisions in (wo of the romds. which would be selected randomly af ics they completed the decisions in all the rouncls." Participants were encouraged (o) think carefully about each of the decisions.

In each round participants were asked io choose benveen option A and oprion B. In each case, option A was a decision to do nothing and therefore keep the NiS 40 (about $\$ 8)^{33}$ hat they were paid for participating. In each case, option B was a decision (o) receive an additional NIS 30 (about \$(i) hat would expose them to a risk of "being caught and required oo pay a line." In (ach case the potentiat time was larger than the additional NIS 30 the participant would receive if she or he chose option B. The potential fines ranged from NIS 35 (about $\$ 7$ ) 10 NIS 70 (about \$15). The probabilities of delection ranged fiom $5 \%$ (o) $130 \%$.

The nentr-seven rounds included the nine types of logically possible combinations presented in table A above, with each of three clifferent expected values. Thus, for each of the nine combinations there were three

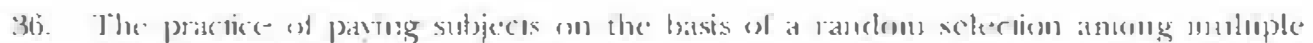

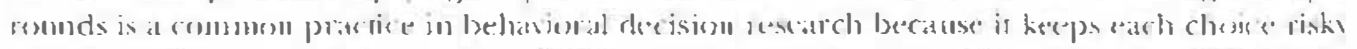

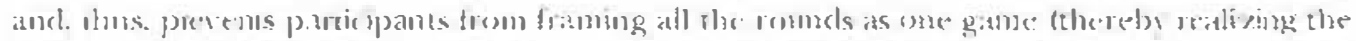

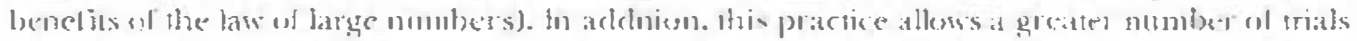

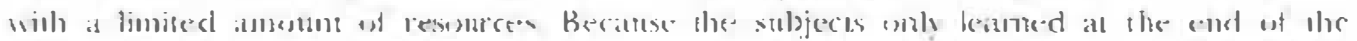

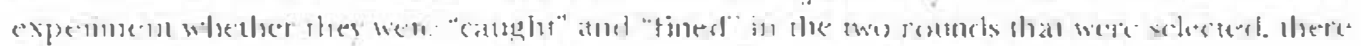

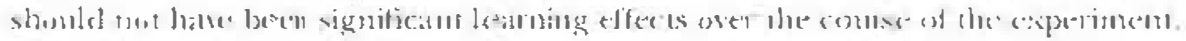

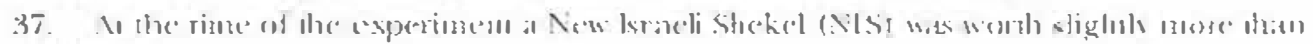
me ams rents. 
founds wirh the same stucture but different experted values. In order in prevent elfects of order. the sequence in which the twenty-seren chosices appeared (m the scretn was arthitrary and changed from one participant in imother. Table B stummarizes the different choices offered to the participants. Recall that in each case. the participant faced a choice between droing nothing (and keeping the NiS f(j) or taking an adclitional NIS 30, stroject to the risk of being caught and required to pay a fine. Table B stummatrizes the different chances of being catught and the different hines raced in each of the twenty-se'en pessibilitic:s.

TABIE: B

SLMMARI OH EXPERINENTA. COMBINATIONS

(EXPEC:TLD VAl.LES: D=NIS 2.4; $\mathrm{E}=\mathrm{N}$ IS $15 ; \mathrm{F}=\mathrm{NIS} 7.5$ )

\begin{tabular}{|c|c|c|c|}
\hline & \multicolumn{3}{|c|}{ SHES SANE:TKOX } \\
\hline $\begin{array}{l}\text { L.WELIIIOCA } \\
\text { OF DE1ECHON }\end{array}$ & (itRTAIN & RISKY & U::CERTAIN \\
\hline ( EFRTIIS & D: IIsta, Nis rio & 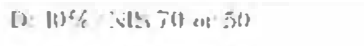 & - I11\%/cis jucer in \\
\hline \multirow[t]{2}{*}{ PROB.aBIIIT } & E. $311 \%$ / NES is) & E. $30 द$ XIS +30 or 40 & 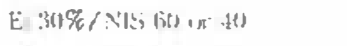 \\
\hline & $F=511 \% / X I S$ t5 & F. $52 \%$ VIS 55 or 35 & F $50 \% \% / N$ IS 55 , $x: 35$ \\
\hline Riskil & 0:.5\% or I5\%/ NIStil & 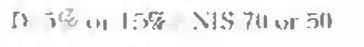 & D. $5 \%$ or $15 \% /$. Nis 7 (1) or \\
\hline \multirow[t]{2}{*}{ P'RUBALIIIIY: } & E: $20 \% \ldots$... HI\% XIS!n & 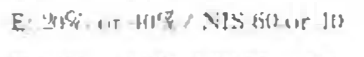 & 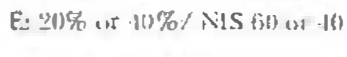 \\
\hline & F. fug or 611\%/NIS 15 & F. $40 \%$ or $60 \% /$ NIS 55 or 35 & F: $411 \% \%$ or (60)/ANIS 5.5 or $\times 5$ \\
\hline LAC:ERTIN & 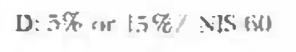 & 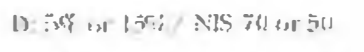 & D: \\
\hline \multirow[t]{2}{*}{ P'ROBBABSILTH' } & E: $2(1) \%(0)+(1) \% / \mathrm{N} / \mathrm{S}: \mathrm{i})$ & 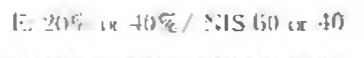 & 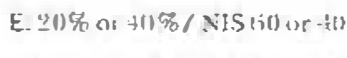 \\
\hline & 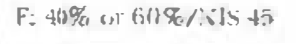 & F: 41$)^{\prime}$ or $60 \%$ / NIS 55 or 35 & 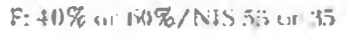 \\
\hline
\end{tabular}

The expected values of all the I) combinations are identical in every cell. likewise with the $E$ and $F$ combinations. The expected values are the expected value of the adclitional NIS 3 (t) that the participants received for taking the action, minus the expected value of the sanction. The expected value of each of the D combinations was NIS 24, the expected value of each of the E combinations was NIS 15. and the expected value of each of the F combinations was NIS 7.5. * Thus. the cxpected value of option B (taking a risk) was always better than option A (cloing nothing).

38. As a review of Table B shms. we varicel the expected ralues by manipulating both the sir. of the sanction and the probability of detertiun. Wic did this in order 10 produce a strong te'st of the effect of uncertainty within au expermincut of manageable duration. If we had raried the experted value by manipulating (m) the size of the sancrion we would be unable to sat wish auv confidence whether uncereainy would have of similat effect at different probability levols. Sinuitarly, if we hat vatied the expecterl value bu ratuipulating only the probability of eletection 
The difference between "risky" and "uncertain" was ats follows. For the "risky" factor, the participants were told that there was a $50 \%$ chance of each of the two possible conditions. For the "uncertain" fartor, the participants were told that there were two possible conditions, but that they could not know the chances that it would be either of the two. ${ }^{\text {sy }}$ This is an option which involves what behavioral economists label "ambiguity." The complete instructions (translated from Hebrew) appear in the Appendix.

After each parucipant completed the twenty-seven rounds, the computer selected two rounds at random. For those rounds in which option $B$ was selected, the participants carried out the lotteries, using a coin to determine the outcome of $50 / 50$ lotteries and a ten-sided die to determine the result of lotteries involving other probabilities. By being asked to toss a coin or a die, participants were given a sense that they were not being manipulated or misled. In addition, the use of the coin and the die (shown to the participants at the outset of the experiment) gave the participants a concrete sense of the probabilities involved. The participants were then paid according 10 the restults and debriefed concerning the goals of the experiment (and promised that their identities and the choices they made would remain confidential).

Our mull hypothesis was that the legal ethos faccording to which uncertainty in sanction is avoided and uncertainty with regard to the probability of detection is tolerated) ${ }^{\prime \prime}$ promotes elficient deterrence. This hypothesis would predict that participants would be neutral or aresse 10 uncertainty in detection while preferring uncertainty in sanction. We also predicted that participants would be averse to the transition from risk to

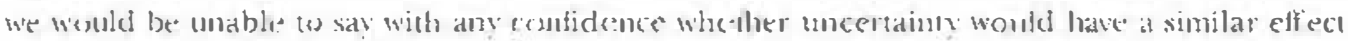
at different sancion ievels. Separalely manipulating he sizt of lhe sanetion and the probabilin sf defection would have reguired doubling the duration of the experineme, dusbling the cost

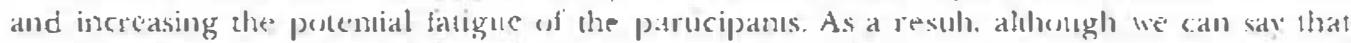
sanction size, probability of derectient. and uncrotaing all alfect participants decisions. we

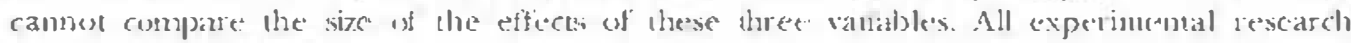
involies arade-ofls of this sort.

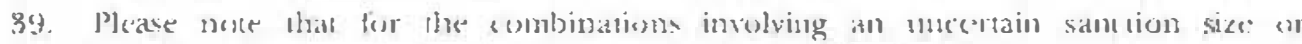

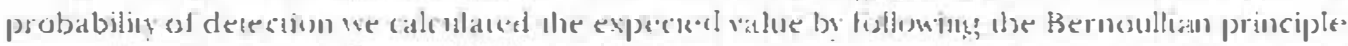

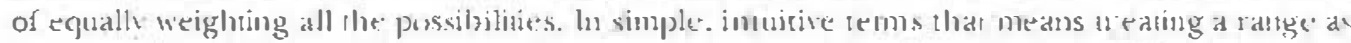

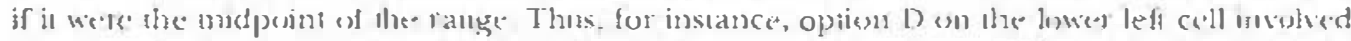

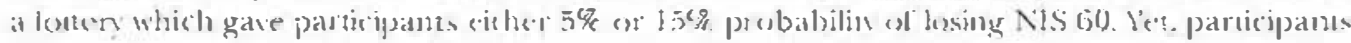

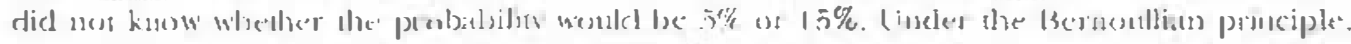

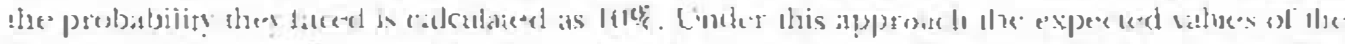

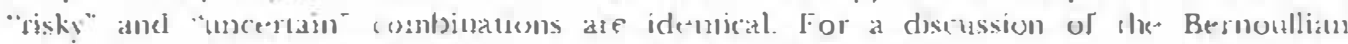

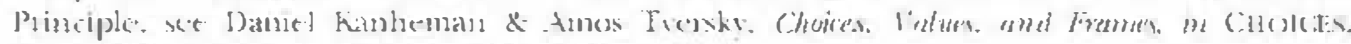

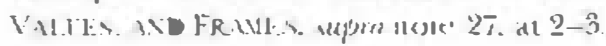

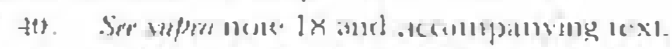

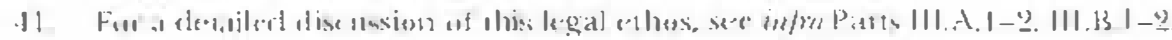


mucertaints. This conjecture wats batsed on the rish literature establishing that individuals are ambignim-atverse."

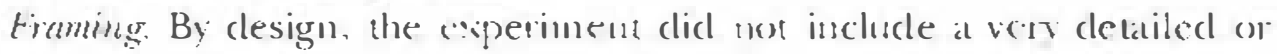
"thick" framing. Panticipants weie not atshed on imagine themselves committing a particular crime or a civil womg. Instead. the instructions simply gatre the participants an unclesstanting that chensing the risky alcermative imsolved commutsing a wrong for which they could be "caughe" and made io pay a "fine." Thus, the instructions stated that "it wou choose option $B$ you will get an additional 30 NS. Bul you face a risk of being callght and required to pay a fine." If anything. the. Hebrew words used for "autugh" and "fine" suggest punishoment for a wrong even more strongly than the English translation. These te:mus were repeated in the instructions preceding each round. The intent was to frame, in as open-ended a form als possible, choice $B$ as a wrongful choice.

We chose such thin framing because there is so litte prior research on the effect of uncertainty on cleterrence. We wished $(0$ isolate, as much as possibte, the effect of uncetatinty. recognizing that thicker framing could produce clifferent results. For example. if choice B were framed so that it involved a say serious wong that woukd strongly viotate the moral sensibilities of resealloh participants and expose anyone who was calught o substamtial shame, it seems quite possible that participants would have been more reluctant a choose option $B$ even in a laboratory concext. The effect of thicker framing requires further rescarch.

of course. this choice of traning is one reason for calltion in drawing strong conclusions from our research. Nevertheless, it is precisely this need for calltion that emphatsizes the signitiance of this kind of research for the enrichment of law and economic andysis. If it is important to exercise caution when drawing conclusions fiom an andysis that is sensicive to the effects of uncertainty but consciousty ignoses the consequences of thick framing; then it is even more important io exercise cantion when clawing conclusions from an analysis that ignores both fiaming and uncertainty.

fn our experiment. the decision was analugous to the gain/loss gambles stuclied by behavioral decision reseatrchers." Participants considered whether to rake the chance involved in choosing 20 accept an additional 30 shekels. If they took the chance, they woutd cither receive a gain (the 30) shekels) or be subject to a loss (a fine that would be greatter than 30) shekels?.

This gain/loss research clesign sharply clistinguishes our experiment from prios behavional decision research on compliance with noms.

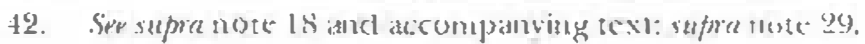

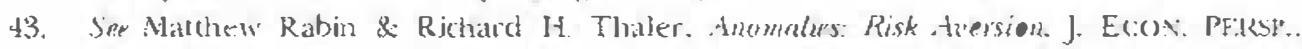

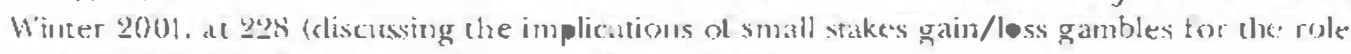

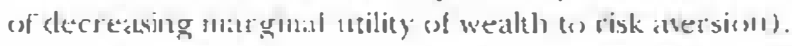


Experiments in prior research hate been caref tally designed so that decisions are obviously and umambiguously lramed as involving either a loss or a gain. This prior research has confirmed the gain/loss framing effect in the contex of compliance with legal norms; namely, people are risk-pref ering when choosing among options that involve only losses and risk-avoiding when choosing among options that involve only gains. White important, these findings are difficult to apply to choices that presest the possibility of gains and losses-which we betieve to be the case in vroy many situations involving the choice (o violate a legal norm. Indeed, the earlier research left open the following very importam question: When people face a decision that presconts the possibility of either a gain or a loss, do they evaluate the "gain" and "loss" onteomes separately. so that they are risk avoiding wirh respect to gain possibilities and risk preferring with respect 10 loss possibilities, or do they evaluate the gains and losses together, so that theis risk attitude depends on whelher they perceive the sum of gains and losses as positive or negative?

\section{1). RISTH\%}

lable (. summanes the jesults. As described alsove, participants were asked (o) choose between option A (in which they stops with NIS 40) and option B (in which they get an additional NIS 30) but are subjected to the risk of incurring a fine). 'The numbers in lable (: denote the number of times option B was chosen (i.e., the choice to take a risk). Every participant faced each combination with three different expected values. Given that there were forty-fom participants, the maximum number of $B$ choices is 132 in each box.

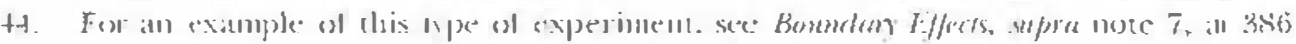

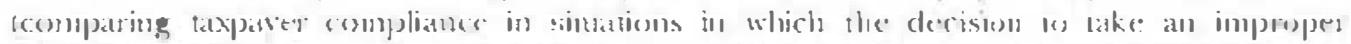

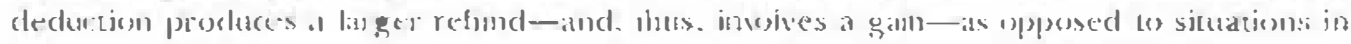

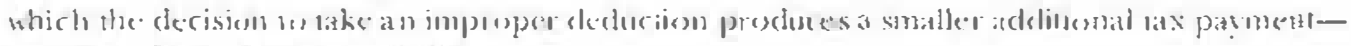

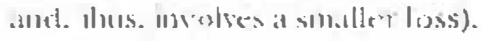

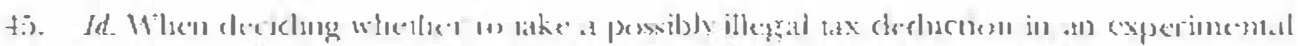

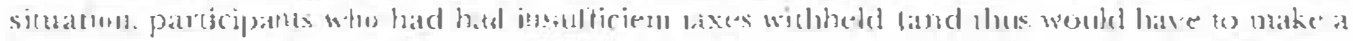

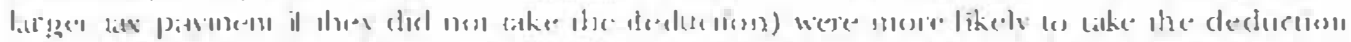

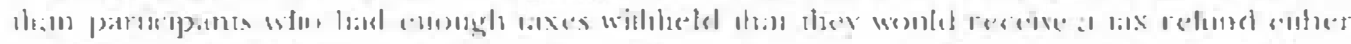

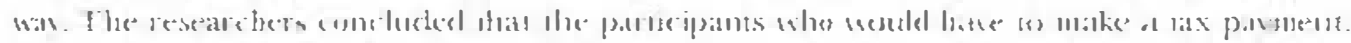

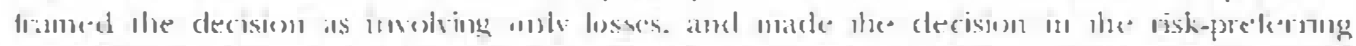

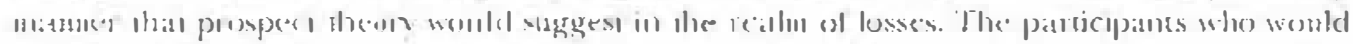

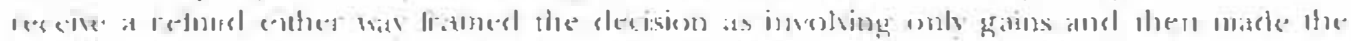

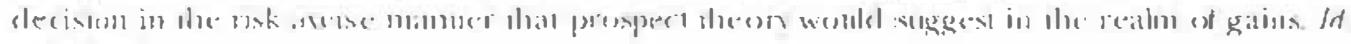
.11 37i-7x. 
T:ABI.t. (

(COMBINED FREQLENCY OH B ( HOIC:ES

(OLT OF POSSIBLE 1.32)

\begin{tabular}{|c|c|c|c|c|}
\hline & \multicolumn{4}{|c|}{ 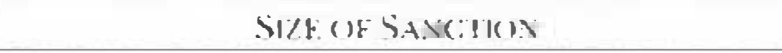 } \\
\hline 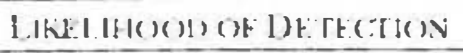 & CERTAN, & RIShY & LEVRRTIAN & Silt \\
\hline (FRTAL: PRC)BASSIIIT & $75(56 \%)$ & $5.3(10 \%)$ & $49(37 \%)$ & 177 \\
\hline RISKY PR()B-IBII.ITY & $60(45 \%)$ & $+4(333 \%)$ & $38(2 y \%)$ & 142 \\
\hline LENCERTAIN PROBABLITY & $52(39 \%)$ & $f+1(33 \%)$ & $31(23 \%)$ & 127 \\
\hline SLM & 157 & $1+1$ & 118 & \\
\hline
\end{tabular}

Table C: shows clearly that the number and percentage of $B$ choices increases with the certainty of the tine and the certainty of the probability of being caught. Thus, the experiment rejected the null hypothesis in part. Participants were averse to uncertainty in both sanction and the probability of cletection. Incleed, comparing the certain/certain cell of Table C: with the risky/risky and uncertain/uncertain cells. the results are quite striking. particularly in lighe of the fact that choice $B$ always had a higher expected value than choice $A$.

Tables D, E, and F show the same data separazely for each expected value (lables $D, E$, and $F$ correspond to the 1$)$. E, and $F$ combinations in Table B). Again, the general patten remains, though the reversal of the expected result in the shift from risky to uncertain probability in Table D suggests (as the statistical analysis contirmed) that the difference bowcen the risty and uncertain combinations was less robust than the differcnce between the certain and risky combinations.

46. Nthough we camnot offer a clefinitive explatnatoon for the reversal of the expected restat in Tiable D. (wo possibilities are as foltums. First. in is pessible that participants weiglited the possibilities in the "uncertain" table using the Bernomblian method of treating equally unknewn pessibilities equalty. This seems unlikely in light of the robust results in other experiments regatcling ambiguty avession and the fact that the expected result is ob:served in Tables $\mathrm{E}$ and $\mathrm{F}$. Second. it is more likely that we ate obsenving a prefterence reversal in some of the participants at a "boundany" in the stusc discussed suthru Part II.B. See supre text accompanying note 27 . Recall that the D chosces involved the higliest expected value, which was the product of the smallest chance ef cleterison ( $10 \%$ in the "certion" cells and $5 \%$ or $15 \%$ in the "risk!" and "uncertain" cells), and the kugest possible line (N'IS 60) in the "certain" cells and NiS 50 or 70 in the "risky" and "uncertain" cells). As Rabin and Thaler have cliscussed. subjects cliffer in their avelsion 10 risk across potential lusses of different sizes and probitbilities. See Rabiu \& Thaler, supro note 43, at 228. It setus platusible that there might be different -lounclaries" for sisky and uncertain chouces insolving misecl gain/loss outcomes. This wruld be a worthy subject for further research. 
IABLE D

FrFquenicy OF B (HOICRS (OUT OF 44 )

WITH EXPECTED VALUE NIS $24^{47}$

\begin{tabular}{|c|c|c|c|c|}
\hline & \multicolumn{4}{|c|}{ Sizt ()\& SANC:T]()N } \\
\hline 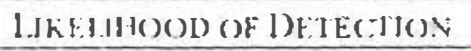 & CHRTAI: & Risk's & LNCFRTAIN & SLIN \\
\hline C.RTAIN PROBABILITY & 37 & $26 i$ & 29 & 92 \\
\hline RISKY PR()BABII.JTY' & 30 & 26 & 22 & 78 \\
\hline UNCI:RTAIN PROBABILITY & 32 & 27 & 23 & 82 \\
\hline Suin & 9 & 79 & 72 & \\
\hline
\end{tabular}

TABLEE

FREQUENCY OH B CHOICES (OLIT OF 44)

WITH FXPEC:TED VALENIS 15

\begin{tabular}{|c|c|c|c|c|}
\hline \multirow[b]{2}{*}{ 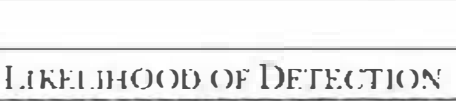 } & \multicolumn{4}{|c|}{ SIYE()F SANGTION } \\
\hline & CFRTAIN & RISKY & UNCERSAII & Si.11 \\
\hline CERTAIN PR()BABIIITY & 24 & 17 & 17 & 58 \\
\hline RIShT PROBABIIIT & 24 & 14 & 9 & 47 \\
\hline UNCERTAN PROBABIIIT' & 15 & 13 & 4 & 32 \\
\hline Stin & $5 ! 3$ & 44 & 30 & \\
\hline
\end{tabular}

TABI.E F

FREQUENT(T) B ( HOSCLS (OLT OF 44)

WTHH FXPEATED VALLE NIS 7.5

\begin{tabular}{|c|c|c|c|c|}
\hline \multirow[b]{2}{*}{ 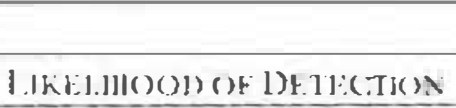 } & \multicolumn{4}{|c|}{ 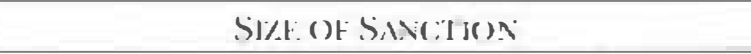 } \\
\hline & CRTAIN & RISki) & LINCERIAN & Si II \\
\hline CERTAIN PR()BABIIIN' & 34 & 10 & 3 & 27 \\
\hline RISLY PROABABIIIT' & 6 & 4 & 7 & 17 \\
\hline UACFRTAN PRCIBABILITY & 5 & 4 & 4 & 13 \\
\hline SL:M & 25 & 18 & 14 & \\
\hline
\end{tabular}

Examining the data demonstrates that both the level of uncertainm and the expected value of the decision appear to have made a difference in the decisions. The more impostant result for our purposes, of comse was the effect of uncertants. The more uncertaint associated with oprion B, the teos likeh participanss wete on choose it. In addition, the higher the experted value of option B. she more likels participants were to choose it. Ahhough

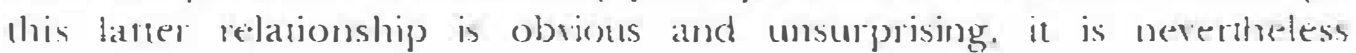

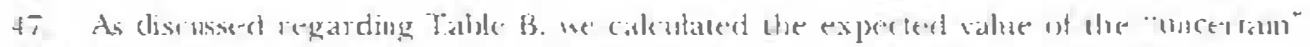
(a) 


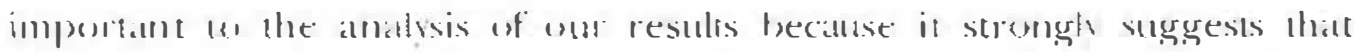
patticipattrs loseh the de decision seriously and attempled wo make rational decisionss.

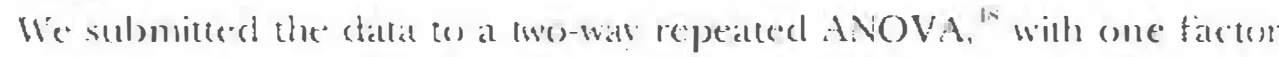
clistinguishing anong the three levels of certainty for the sanction, and another fincor clistinguishing among the the tesels of certainte for the mobability of being alleght" We find at significant effect of sanction

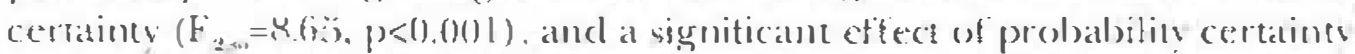

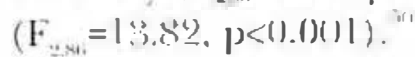

There is a slrong. significant difference between the cortain sanction and the rwo ancertain andions (risk and uncertainty) posted together $\left(F_{1: 1}=1(1.62, p(0.1) 1)\right.$ and moly a matginally significant difference between riske sanctions and ancertain sanctions $\left(F_{1.0}=2.9 . p=0\right) .1(1)$. The result is similas fon the cortainty of the probability: namely, there is a strong, signiticant diflerence between certain probabilities and the two uncertatin probalsilities pooled wegether $\left(F_{1,}=22.19, p<(0.0) !\right)$ and only a matginally signitican difference benwen risky and unceltain probabilities $\left(F_{1,1}=3.34\right.$, $p=(0.07)$. (Overall. these fincliugs suggest that behaviog is influenced by certainy (both cortainty with resped to the sancrion and cortanty with respect (1) the probability of cletection), while the difference between risk and uncertaing under the conditions we tested is smaller and only mavginally significant.

\section{F. MTHEHETATONOH RESLITS}

- Accorcling to (sur results, uncertainty with regard (o) eirher the size of a sinstion or the probabilin of cletection increases deterronce. To differing clegsecs, these resulds pose a challenge to interpreation in light of both prospect theory and expected utility theory." In the end, the results can be

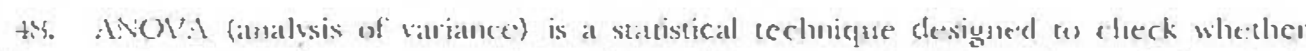

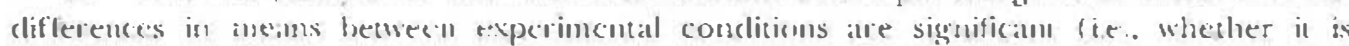

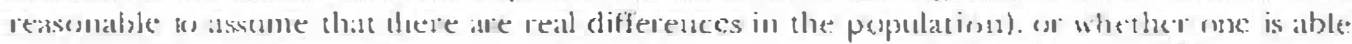

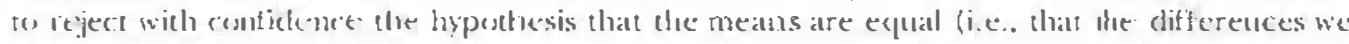
sec alle just "moise" iu the samples.

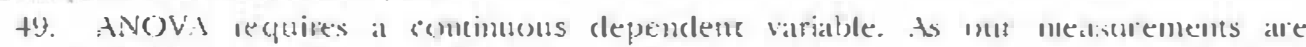

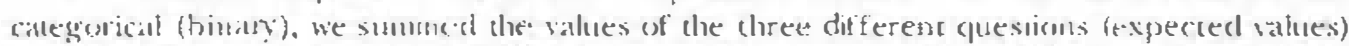

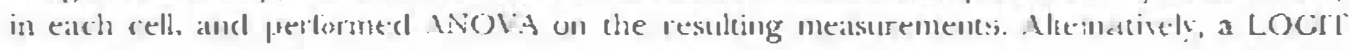

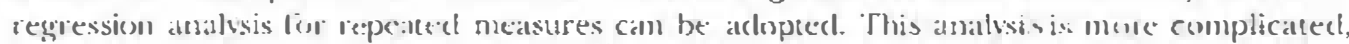

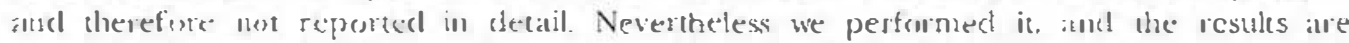

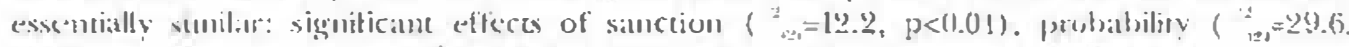

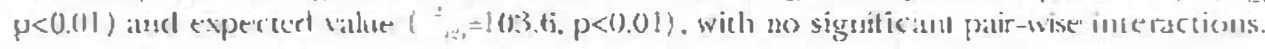

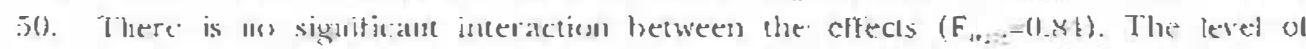

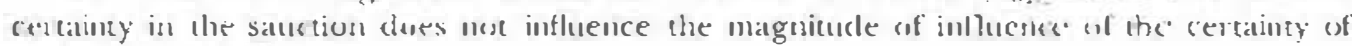
prebability: átucl vice versid.

51. Prospert theorly is hat nathe given to the branch of behanional clecision research

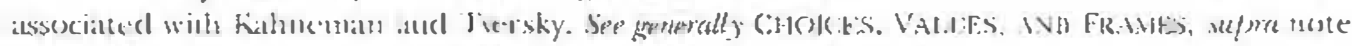

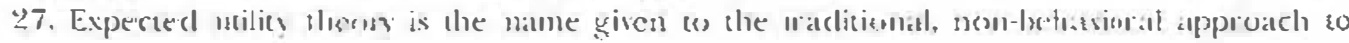


entisely reconciled wish prospect theory. but only partially resunciled wish expeced utility theos?.

W'e discuss separately the transitions from certain to risk sanctions, risky to uncertain sanctions, certain to risky probabilities. and risky to uncertain probabilities.

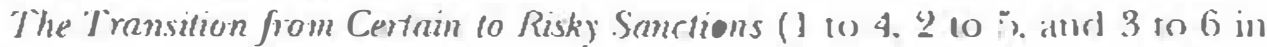
Table A). This transition increases uncertainty with regard (o) losses. Thus, consistent with the reflection effect observed in prospect theor rescatch, we might expeco participansts to be risk-preferring. Indesed. his was the prediction made by one of us in an earlier article." Jie. our restalts demonsirate risk aversion-lhe result that would be prediched h axpected urility theory, which prospect theory research has demunsuated (o) be deficient in important respects.

the apparent combadiction can be resolved through the recognition lhat the $B$ options in ous experiment imvolved gains as well ats bosscs, and that the potential for gain consistenty outweighed llo potentiat for foss. Prior experimental research on compliance with legal momm was catrefulls: constructers so that there were mo mixed gain/loss options. In that context, the resoatreles found. consistent with the gain/loss froming effect explained by prospect theory, that participants west risk-puterong when oprions insolved only losses and rist-avoiding when optiom innelved only gains. By contrast, oun experiment presented the more immpley (and realistic) situation in which both gains and losses arte posible mucomes of the violation of a legal nosm.

This design raised llue question whether participants wemld frame alue loss and gain possibilities separately-behaving in a rish-pe-forving manner with regard io uncertansy over losses and a risk-avoiding manmon with regard to uncertaint over gains-or whether the participants would frame

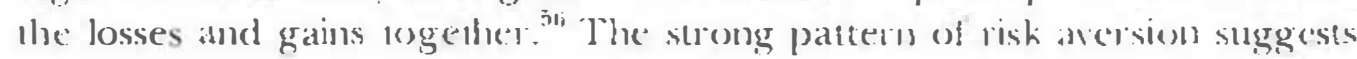
that hie participants fiamed the sanction, not ats a less. bull rather as a

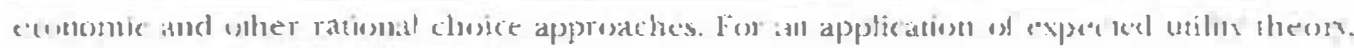

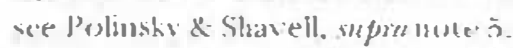

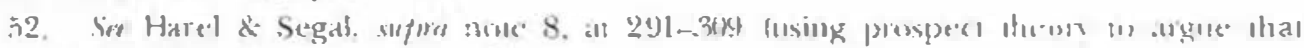

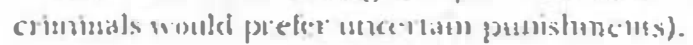

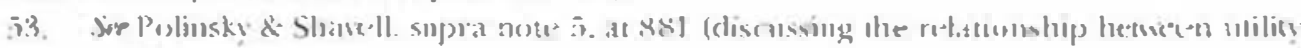
theory and riwh arersion).

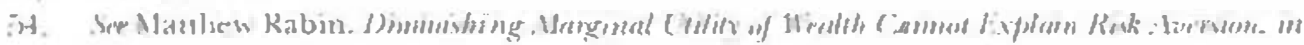

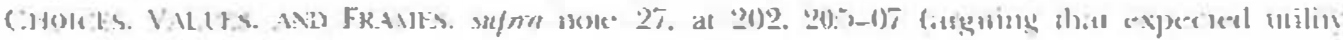

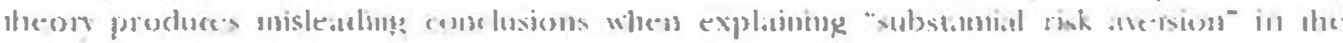

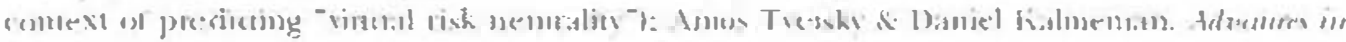

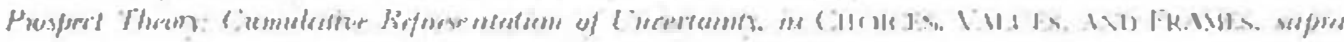

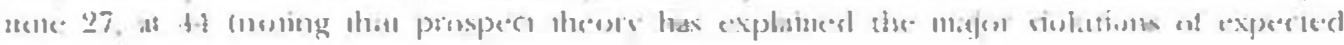
utility uhe (s)

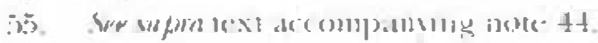

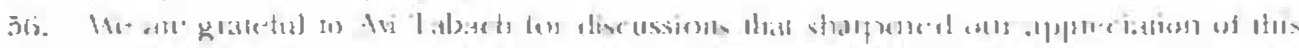
pensu 


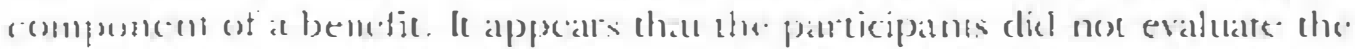
sinction in isolation. Isul rather in conjunction with the bentit derised from making the risky chosice. In othe: words, in deciding whether ro choose apsion 13 , the participants discounted the value of the addieional 30 shekets accorcling lo the chance of being catught and fined. The more certain thes could be about the chance of being caught and fined, the more certain thes could be about the gain from option B. In this way, the participants appeall (o) have fiatured option $B$ as presenting the possibility of a gaitu. with th: resuluing risk averse behavior that prospect theory predicts with regard ou gains. (of course, more rescarch is necessary before drating strong conclusions regarding the framing of such gain/loss decisions.

The Transition from Risky 10 Lincertain Sarctums (t) to 7.5 to 8 , and 6 (o) 9 in Table A). In contrast, this transition an be easily explained. The results here reflect ambiguity aversion-a well-clocumented preference for known wet unkmown probabilities. sin

The Transition from Certain to Risky Probabilities (1 1029,4 to 5 , and 7 10 8 in Table A). The deterrent effect of the transition from certain to risky probabilities of detection is the experimental resulz that is most inconsistent with the expected utility analysis." Prior work in economics has taken risk atersion into account; risk aversion mas explain the preference for certain satnctions ine risky sanctions (because there is a broader lange of sanctions

-i7. Ihis aspect of nut results has tos be considered at stmewhat weak finding because: it is

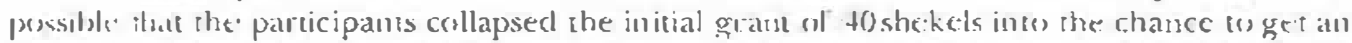

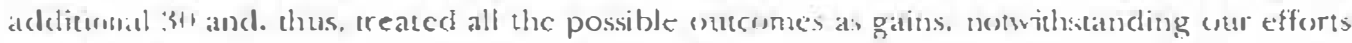

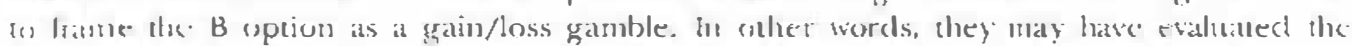
chence heowern A and B, not as we fiamed it (i.e., becween (A) "keepring" fo shekefs itnd (B)

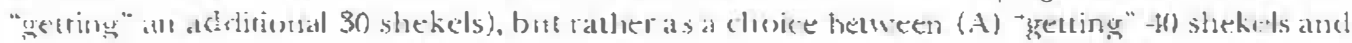

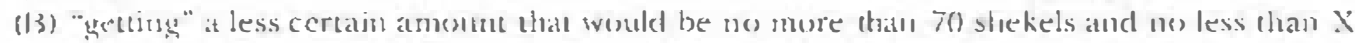

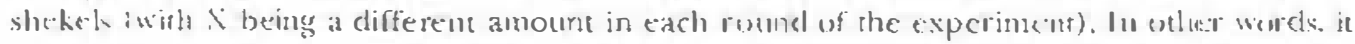

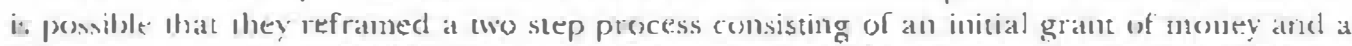

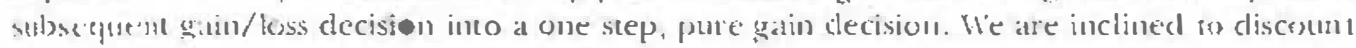
this pussibility becatse belatrioral elecision research stromgly stopports the hyprothesis that

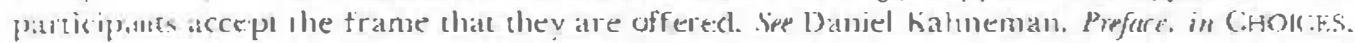

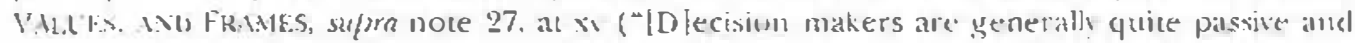
hetetent inclined (o accept any frame to which they are expessed."). As shrow in the instrutuous in this Article's Appendix, the participauts were told:

Ii tlu begiming of cach round you will he given 40 NIS. Then yu will be asked to

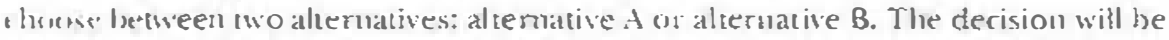
comclusted by clicking a buton with the musust. If you chosese A vou will keep the: f1) Vif: and the round will end. If you chosese $B$ you will be" given an extra Y NIS. lsul you will num the risk of being catught and requaired to pay a finc. lu this case sul will hase to return money to the experimenter.

Lier enfm Ippendix. This fanming issute remains to be explesed in subsequent research.

ix. So supratext accompanying note 18. Sep generelly Buclescu. supra noste 29.

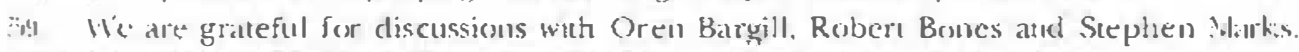

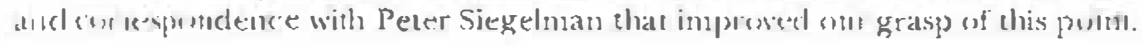


in the risky case), but it cannot explain the preference for greater contanu with regard to the probability of detection."

Increasing uncertainty abous the probability of detection does nos increase the range of sanctions or, ex ante, the chance of detection. Befort rolling the ten-sided die that determines the probability of detection, an individual choosing $B$ in our "risky" cells faces exactly the same probabilits of detection as an individual choosing $\mathrm{B}$ in ou" "certain" cells. Thus thr. shifts in the results that occur in moving from the "certain" detection to the "risky" delection cells are results that camnot be explained within the traditional expected utility framewort.

Another way of emphasizing the potential significance of our detection finding is that prior theoretical analysis improved on the expected unilit approach by recognizing that, because of risk aversion, individuals bethation is not dictated solely by the expected value of the sanction." Insertanm with respect to the size of the sanction makes a difference because of risk aversion. Onr analysis makes a further imprevement by recognizing laat individuals behavior ma $v$ also differ systemalically from expected value when there is uncertainty over the probability of detection.

The Transition from Risky to Uncentain Probabilities (2 to 3,5 to 6. and is 109 in Table $A$ ). The increased deterrent effect of moving from "risk!" (o) "uncertain" is more consistent with expected utility analysis becanse one camot with confidence state that the "expected value" in the "risks" and "uncertain" cells is equivalent. The expected value is dependen upu the way that the lotery is conducted in the "uncertain" cells, and we did not tell our participams anything about how that lottery would be conducted. Moreover, as noted in comncetion with the transition from risky to uncertatu sanctions, prior research on ambiguity would predict that indiviruals would be more relactant (o) tolerate unkmown probabilities of this type than known ones. ${ }^{62}$

The importance of atsitudes toward risk suggests a further reasom for caution in generalizing from our results. There are findings that snggest that the degree of risk-1olerance with respect to small risks, such as small monetary losses. differs from the artiundes to large risks. ${ }^{\text {tis }}$ as a result. one

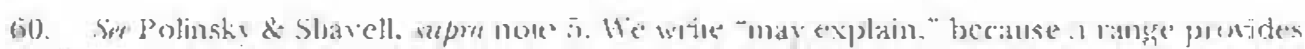

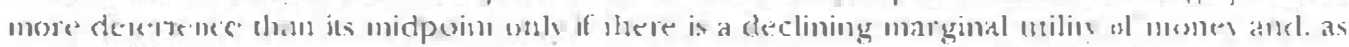

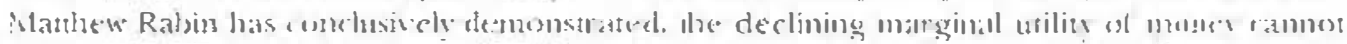

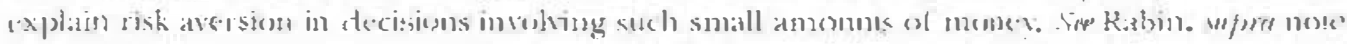

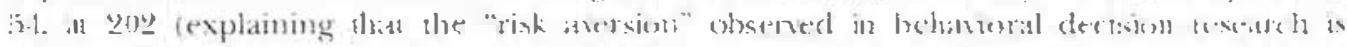
.

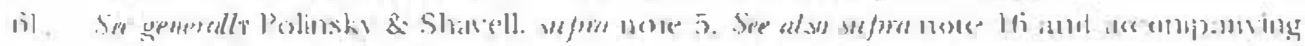
в

tie. See supra iext accompanying notes 18, 29 (discussing individual preferences for risk aip (as).

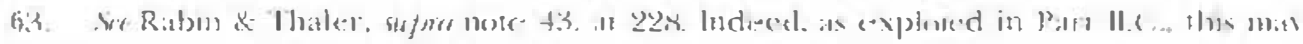

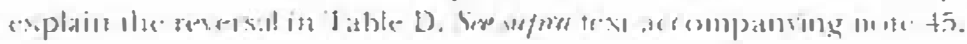


Camon lighty generalize the results from behavion involsing small stakes to bethanion involving lange gambles. As threse cantions make cleat. we clo non claim that ont research and analy sis are conclusive with respect on the effects of Incertainus. Rather. we highlight the importance and seterance of uncertantr and begin (o) explore the wavs uncertants could be manipulated to recluce the costs of eperating the begal system withesut reducing its deterent effects. Foward that end, the next Pan athalyes the treatment of uncertainty in tort and criminal law and singgests ways that policy makers conld use uncertainty to increase cleterrence.

\section{LACERTANIT IN CRIMINAM AND TORT LAM}

()ur experimental results suggest that uncertainty in sanctioning increases cleterence, at teast within the conclitions that we incstigated. In this P'art, we address the treatment of uncertainty under existing tort and criminal law, begimning with the anomaly that we noted in the intreduction: namels, that criminal and tort law both attempe to reduce uncertanty with respect to the sire of the sanction and lasgely ignore uncertainty in detection. This anomaly reflects a cliscemible legal ethos that, nevertheless, lcaves substantial rom for policy makers to explnit the cleterrent possibilities of uncertainty eren in setting sanctions.

\section{A. UNCRTTAINTY IN CRIMINAL LAW}

Criminal law differcutiates sharply between cortanty with rospect to the size of the sanction and ertainty with respect to the probability of detection. Criminal law has mechanisms clesigned to increase certanty with respect to the size of the sanction. but it sypically cloes not regulate centainty with respect to the probability of decection.

\section{Encertainsty Regarding Sanction in Criminal $1 . a n$}

There are many mes in criminal law that are explicity clesigned to adcliess uncertainty with respect to the size of a sanction. These moles follow in part from the fundamental principle that an individual is entitsed te know in aclvance the conecent of criminal prohibitions as well as the sanctions for violating them. The probibition on retroactive changes in the criminal sanctions provicles a paradigmatic example. Intemational documents, such as Section II (2) of the Unircrsal Declanalion of Human Rights and Section $7(1)$ of the European Convention of Human Rights, prohibit the imposition of retroactive sanctions for new offenses, or retroactively increasing the sanctions for existing offenses. Similar provisions can be found in numerous constitutions, including in Article 1, Sections 9 and 10 of the United States Constitution, Article 10):3(2) of the Creman Constitution. and in Section 
11 (g) of the Cianadian (:harter of Rights and Freedoms." A related principle of criminal law-the principle of lenity-also increases the cerainty of the criminal sanction. According (o) the principle of lenity, at criminal statute must be strictly construed and any doubt regarding the size of the sanction must be resolved in favor of the defendant. Finally, one of the stated objectives of the Model Ponal Code has been "to give fair wanning of the nature of the sentences that may be imposed on conviction of an offense." This objective was a central rasion for the move in the United States toward determinate sentencing exemplified by the adoption of detailed sentencing guidelines. ${ }^{\text {i7 }}$ To sum up. it seems that in Western legal systems. certainty in

64. These provisions prohibut boul the remoactive imposition of bew prohibitions and the

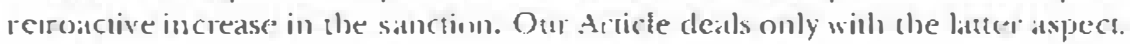

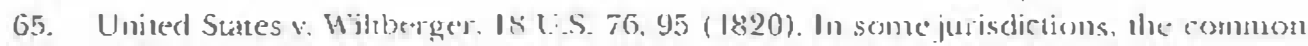

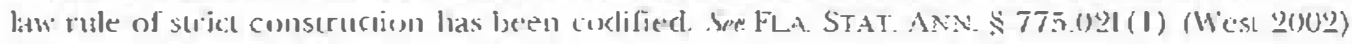

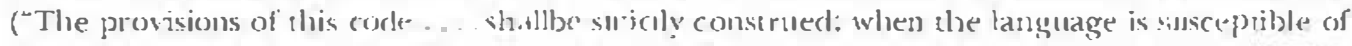

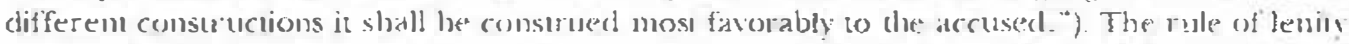
is often justified on the grounds that citizens have a tight in be llotified of the comtent of criminat prohibitions as well as the sise of she sanctions imposed for violating llese

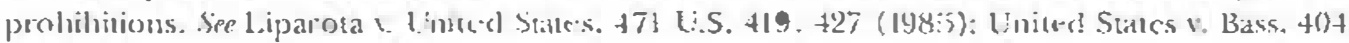
U.S. :336, 347-48 (1971). For a discussien of the rule of lenity, see gemerally Dan M. Jiahan.

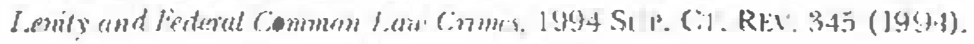

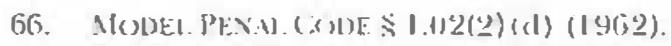

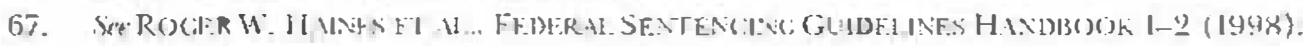

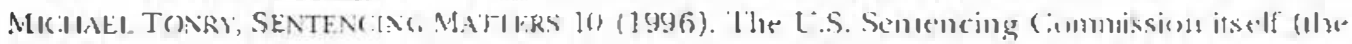

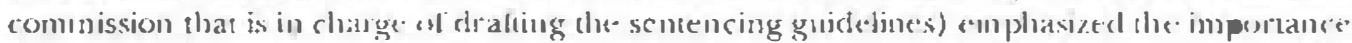

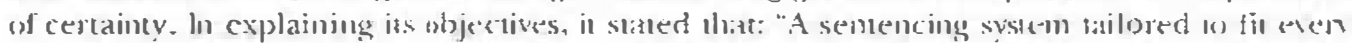

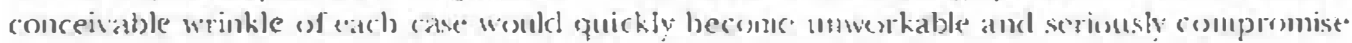

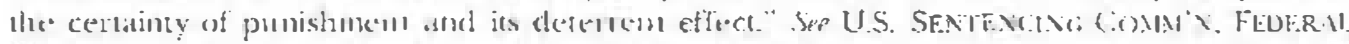

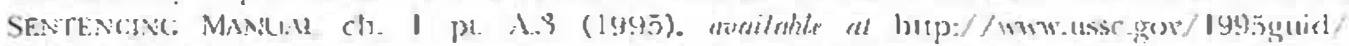

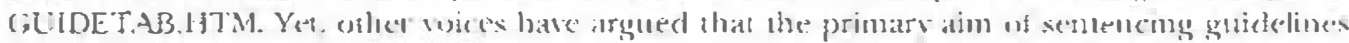

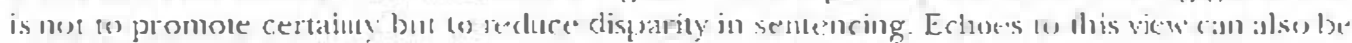

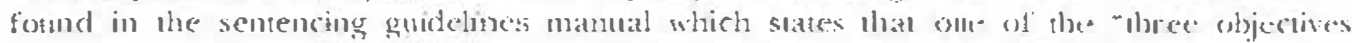

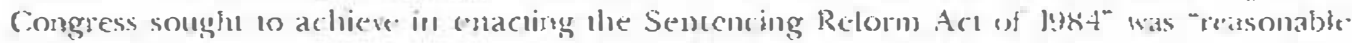

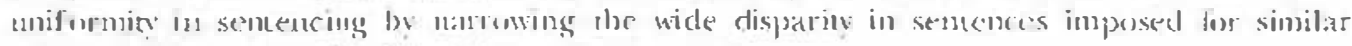
criminal ollense commited by similas offendiers." $/ d$.

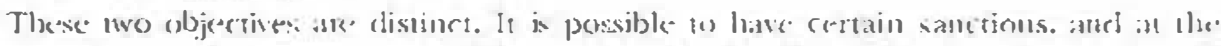

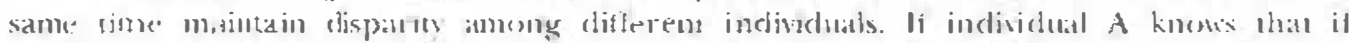

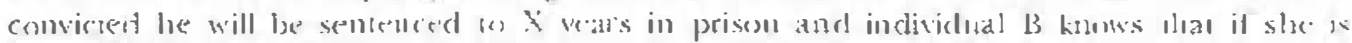

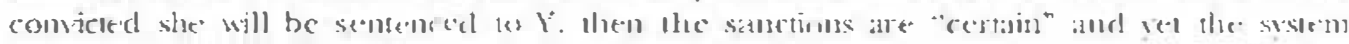

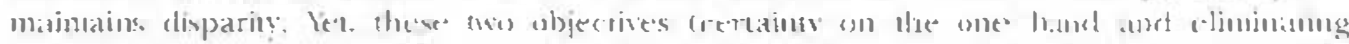

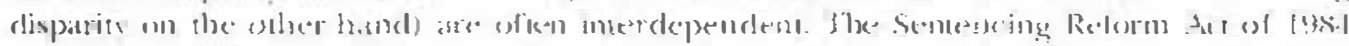

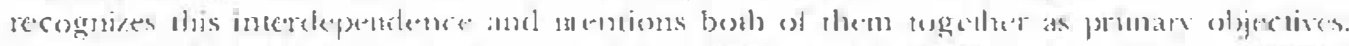

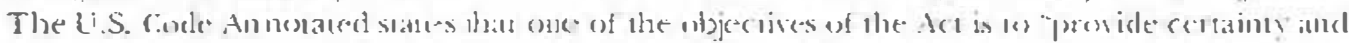

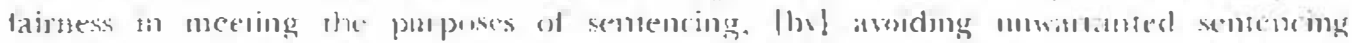

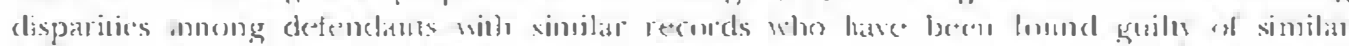

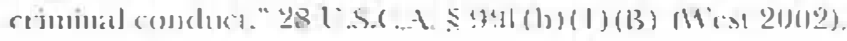

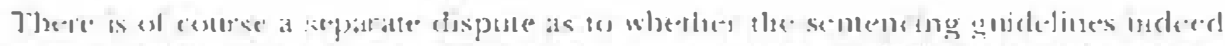

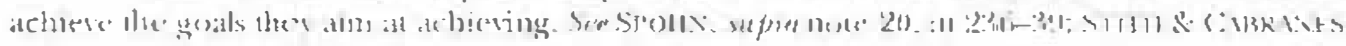

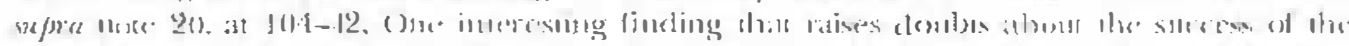

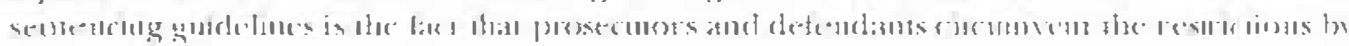


semencing is considered an impertant objective and munerous dondrincs dre designe:d wathieve that certainty.

\section{2. (Incertainty Regarding Detection) in Cominal Law}

We do not ebserve the same attention to reducing uncercainty regarding the probability of detection in criminal law. In large part, this may lx attributable to instiutional factors. The criminal justice system se parates instiutional respensibility for different aspects of the detection of criminal arts. Police and other law enforcement agencies are responsible for sureillance and arrest; prosecutors are responsible for deciding whether and how to presecute; and judges and juries are respensible for deciding whether the evidence is sufficient to convict. White overly simplistic, this description highlights the fact that a variety of institutions are insolved in detecting crime and that. while courts are hardly peripheral to the detection process, they do not play as central role in detection as they do in sentencing. This lesser role of courts is important because, in general, the more removed an actor is from the inside of a courtroom, the less the legal system tends to consmain action. Thus, as a matter of institutional reality, certaincy in detection will tend to be affected more by "pelicy" than "law" (recognizing that we are drawing to some degree an artificial distinction), at least as compared to certainty in sanction.

The existence of agencies specifically responsible for cletecting crime maties it possible for the criminal justice system to address explicitly the public's perception of the certainty of detection in a way that, at least potentially, distinguishes criminal law from tort law. It is our impression, however, that, on the whole, law enforcement agencies' deterrence strategy locuses more on (increasing) the probability of detection than on the certainty of the probability of dercction. Thus, the efforts invested in generating certainty with respect to the size of the sanction are not matched by similar efforts to address certainty with respect to the probability of detection. The former ctimension-certainty with respect to the size of the sanction-falis within the ambit of concerms about the "rule of law," while the latter dimension is merely a matter of "policy." While this differential treatment of certainty with respect to these uvo dimensions may seem natural to some and puzzling to others, all would agree that the lack of certainty with respect to the probability of detection receives little or ne attention.

rolgaging in more pre-charging charge bargaining. See Ahmed Essam Taha. The Elfecis of the Forieral Sentencing Guidelines on the Disposition of Cimmal (ases 11)(1)-01:3 (1996) (umpublished Ph.D. clissertation. Department of Ecomemics of Stanford Linisersicy:) (on filc with the lowa I aw Review).

68. Prosecutors are in lace often insolved in surveillance and arrest and, through plea largaining, they can also become juigh and jur?: 


\section{Manipulating Uncortaints in Criminal I.aw}

Given that we are suggesting that policymakers should consider manipulating certainty in order to increase deterrence, the onus is on us to demonstrate that this is possible. Hence, in this section we will suggest some ways in which certainty in sanction size and detection can be manipulated without subverting legal doctrine, or betraving the legal ethos. ${ }^{64}$

Santion Size. Criminal law often authorizes officials to use their discretion in setting sanctions. How officials use this discretion can increase or decrease certainty with respect to the size of the legal sanction. Although determinate sentencing reduces the discretion of judges, it does not reduce the discretion of police and prosecutors. Most notably, prosecutors retain discretion to charge offenses up or down." In addition, broad grants of federal criminal jurisdiction in the Linied States can expose defendants who cormmit identical crimes to disparate sentences depending on whether they

69. While this section focuses on the certainu of the sanction and the precision of the probability uf detecrion, what is ulimately crucial fu dectrence is not centairty itself but the

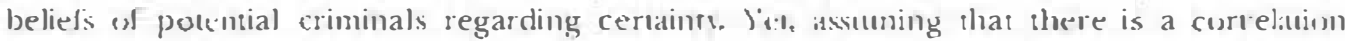

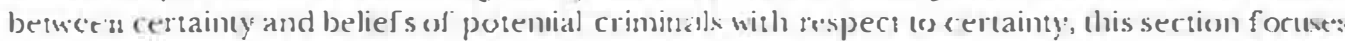
m) the mechanisms for manipulating certainn:

In addition to manipulating beliess conceming the certaints of the sanction and beliets ancerning the precision of the probahilits of atesection, the legal system can alsos manipulate the belie:l's concerning phe average size of the sanction and the: average probabilin

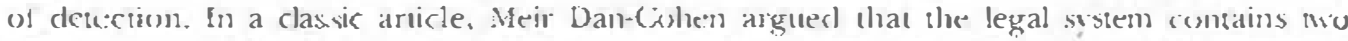

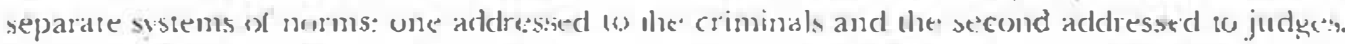

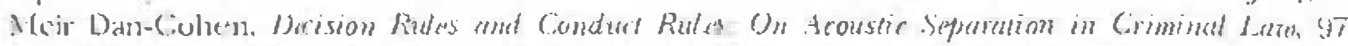

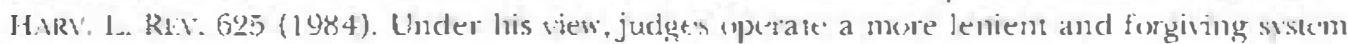
of nurms than those that are belined by the publit w guide judirial decisions. An "acosustic separation" between these mo systems of motrs guarantes, that the norms which are acmalls (uperati-d by judges will not be the ones known (1) the public at large. A similar scheme could perlaps be established with respert w the probability of dectection. The police could create "acoustir separation" between the actual probabilits of deccrion and the beliet of litc probabilirs uf detection used by indisiduals to guide their behavior. In other words, the policc. could manipulate a false belief that he rate of delecuon is much higher than it is in realits.

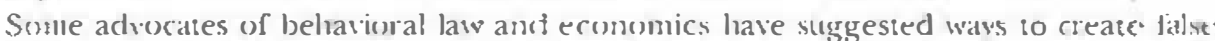

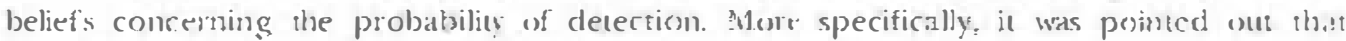

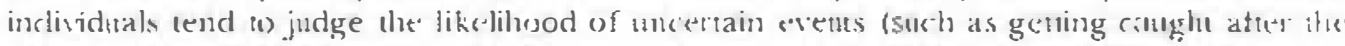
commission of a cuine) by how abilable such imetance's are to the human mincl. This anetwis

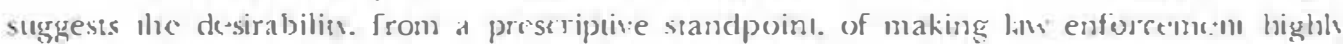
visible and therebs creating false beliets with sespest to the probabilis al delection.

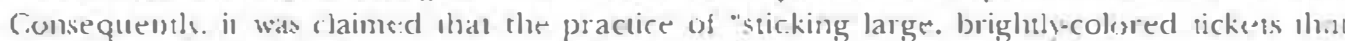

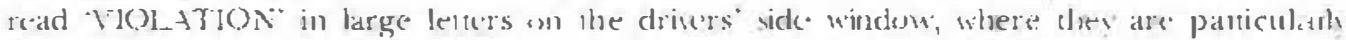

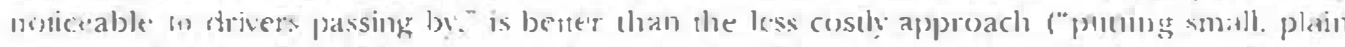

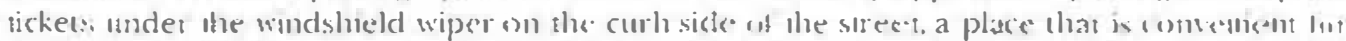

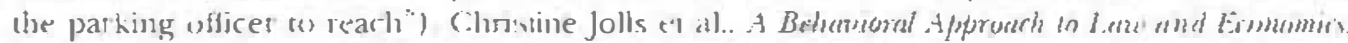

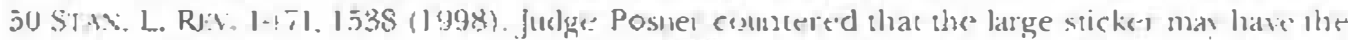

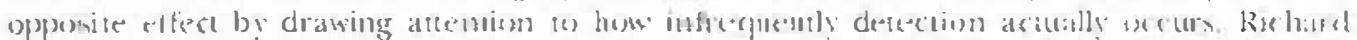

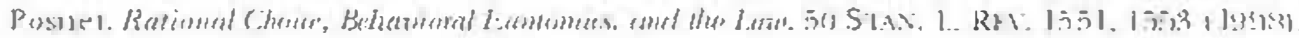

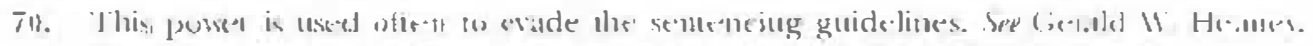

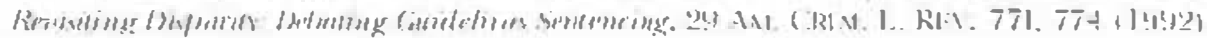




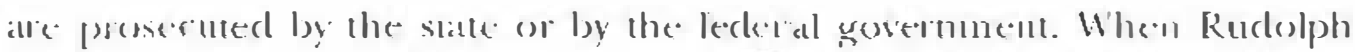

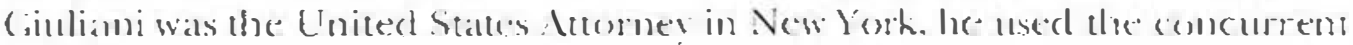
jurisdiction to reatt: at sentencing lottery. His; plan insolved a program is which onte daly was chosen an random ealch week when all streed level drug de'alers apprehended by local atuthorities would be prosconted in federal

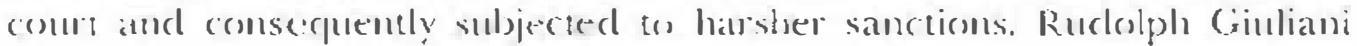
explicith embraced the detcrent posibsilities of sentencing loteres when he statced: "the icleal wals to creatte a kussian roulette e.ffect. ${ }^{.71}$

l.cyal cluctrine cant also increase or clecrease retaints. For example, if sanctions are smaller for attempts than completed crimes, there is musertainty, ex anse, with respect the size of the sanction. When a person stats commitsing a crinte, sle cammot know in advance whether the crime will be completed strcessfully or mo. "Thus, she laces a "scintencing lotery" of sorts." Similaty, sentences sometimes depend on the degree of success of the person in committing the crime. Some penal pronisions impose differential sanctions in accordince with the amount of money a property stolen or other factors unknown to the perpetrator of the crime at the time the crime is committed." Finally, the "Pinketum rule." which makes criminals liable for the acts of their co-conspirators, similarly imposes a sanction according (o) lactors that are not known (1) the perpetiator at the time the crime is committed. More particularly, each co-conspirater bears the riș that other co-conspirators will commit further unplanned crimes." These rules are often considered to leave the fatte of offenders to contingencies that are bevond their powers and therefore are considered unjust.

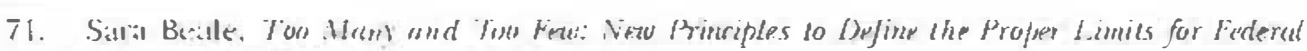

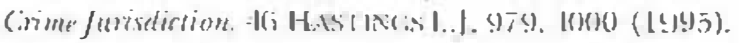

72. A simple example can illustrate how is legal system call manipalate certainty by chatuging its treatunetu of alle muts in at way that is conchucive (1) efficiency. Asstunc that a) of the criminats who statt (1) (umuml at crime complete the crime successtully. Assime: that $10 \%$ of

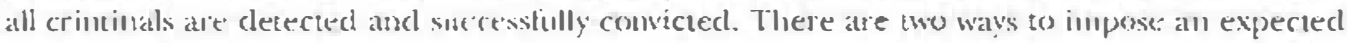

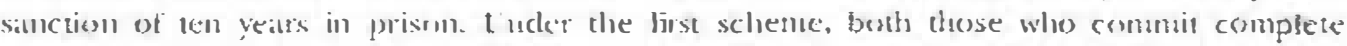
crimes and those who tailed! a connplete them receive ten yeats in prison. Linter the second

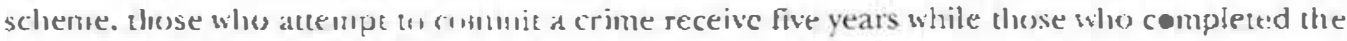
crime reccive tifeen yens. In hesh setuemes. the criminal taces a sanction of unc same expected

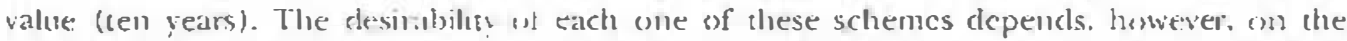

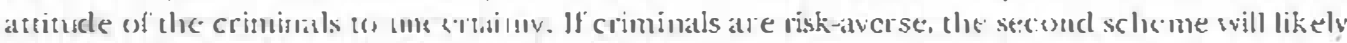
be more elfective llan lle tiest.

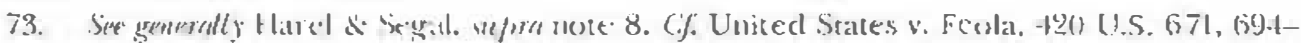

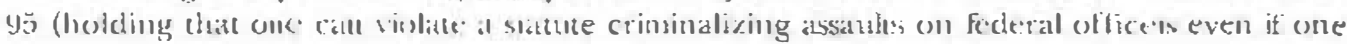

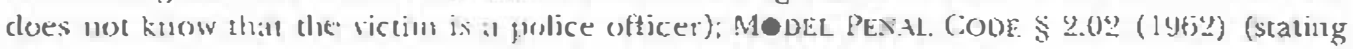
(hat the mens rea regniremenis applin unly to the material elements of a crime)

74. Sere Neal kuniar hitnill. Cimsfiraty Theory, 112 YALE L.\}. 1307, 1363-6-1 (2603) (using the detertent effect of une ertatus is a justitication for the Pinkentom rulet.

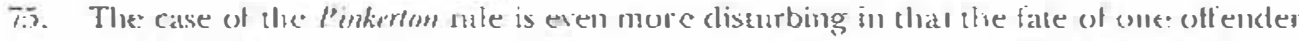
is all the balnds of others. Ne man le willing to tolerate senne cirrumstances in which 
Probability of Detection. The ability of law sulorctment agencies 10 manipulate the certainty of the probabibity of detection vaties according 10 context. One arena in which it seems quite possible is taxpayer compliance. Tax law enforcement is based largely on investigating a representative sample of potential offenders. The more the criteria for auditing and the size of the sample are publicized, the more certanin the detection rate. Prior behavioral decision research on taxpayer compliame suggests that, provided that sufficien taxes have been withlseld from wages. reducing the certainty of the probability of detection woulclincrease taxpanc. (ompliance. ${ }^{\text {it }}$

Enforcement of parking laws (or perhaps miner watfic violations) is another arena in which certainty could be affecred similatly. Many citizens are exposed on a daily basis to the enforcement uf naffic and parking haws and can develop expertise with respect to their enforcement. For example, a municipality could decide to send parking insprecors ressulaty $(0$ all neighborhoods of it could decide to concentrate its efforts on differesut neighborhoods on different, landomly sekered dass. The latter system creates greater uncertainty with respect to the probalsilin of detection. A parking enforcement agency could change the crrtainty of detection by ammouncing (and then following through on the autnounc(ment) that it was going to adopt a less (or more) predictable parting ticket enforcement patlem.

Certamty (an also be manipulated in oller areas through the use of enforcement campaigns. In an enforcement canpaign, a law enforcement agency targets its resoneses in a specific geographic anea or on a specilic type of offense. If increasing uncertainty increases cleterrence, a policy of conforcement campaigns would produce greates deterence than a policy that allocated a constant stream of resources lo enforcemem by geographic area of upe of offense." An enforcement campaign increases the uncertains of the probability of detection bs publicizing the latct that: sometimes, the probability of detection will be very high. Although the

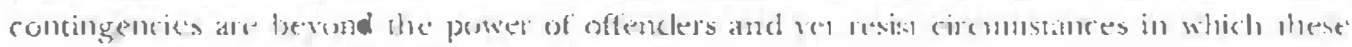

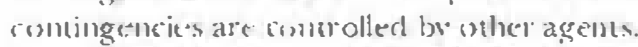

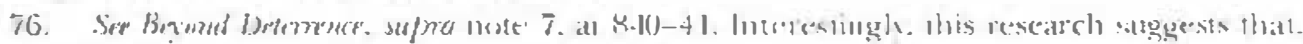

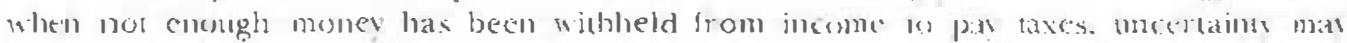

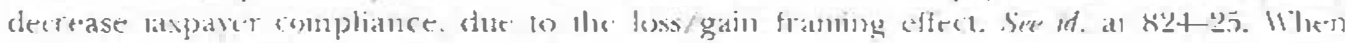

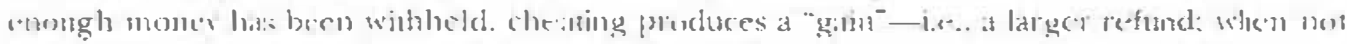

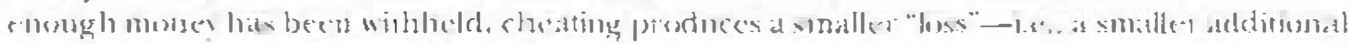

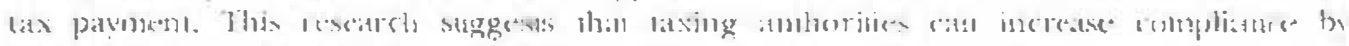

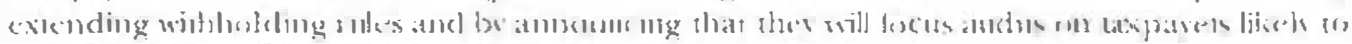

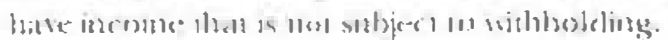

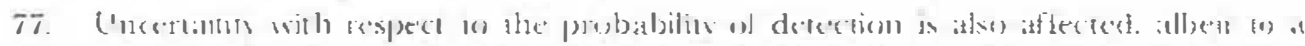

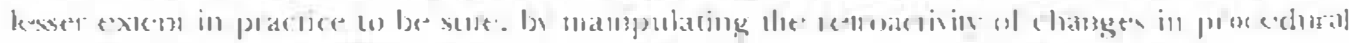

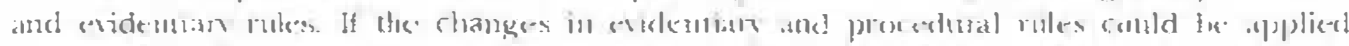

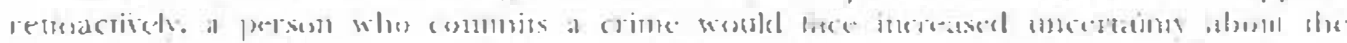

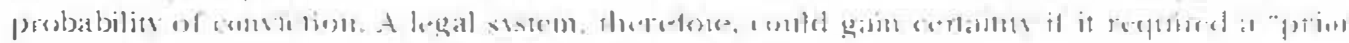

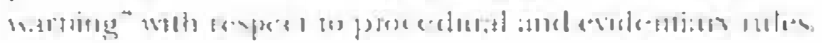


public presumably is awate that law enforcement officials camos consistemtly matistain a high probability of detection in every time: and place, the fact that somerimes the probability will be verv high means that there is a wider range of potential probabilities of detection in any particular cime and phace. Thus. enforcement campaigns have the potential io increase cleterrence. given tixed resources, not only by publicizing the fact of law rnforcement activity (Ihus recruiting the "availability hemistic" to suppor law enforcement efforts) but also by increasing the uncertainty regarding the probabilitw of cletection.

\section{B. UNCERTAINTYIN TORT LAW}

Tort law also differentiates between the treatment of uncertainty with respect to the sanction on the one hand and uncertaing with respect to the probability of detection on the other. Uncertainty with regard co sanction is addressed directly by the law of tort damages and, indirectly, by liability insurance. Alhough tore law's compensatory purpose introduces an in escapable elcment of uncertainty into the expected value of tort sanctions. liability insuranse substantially reduces that uncertainty. In contrast, uncertainty with regatrd io detection is not addressed all all.

\section{L'ncertainly Regarding Sanction in Tont law}

In cort law, questions of sanction are adclessed under the general heading of "clamages." At the level of tegal cloctrine. tort law appears less concerned with reducing uncertainty in sanction than criminal law. This docunal difference follows from the compensation and victim-centered focus of cort damages (as opposed to criminat sanctions). Because of the focus on the harm to the victim, it is often quite difticult for a potential tortfeasor to know in advance the amount of clamages that would be assessed in the event of cletertion. One dramatic example of this is the "eggshell skull" rule, pursuan to which the clefendant is responsible even for unforeseeable harm to a foreseeable victim. ${ }^{79}$ A second dramatic example cornes from the liability provisions of the statutory tort created by the Comprehensive Envirommental Response, Compensation, and Liability Act (CERCLA). ." Pursuant to CERCLA, a person who shipped only a small amount of hasardons waste to a site can be jointly and severally liable for the clean-up of the entire site, even if the person reasonably believed that the waste was not haratoulous."

78. See Jolls re at. supra note 69.

79. See gencrally Benn 1. Thentas, 312 N.W.2d 537 (Iowa 1994) riscussing the "eggsthell skitil" rule of turt litw).

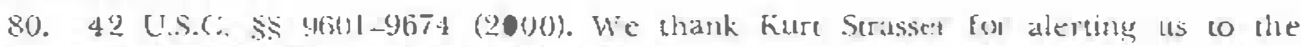

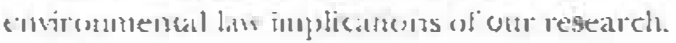

$81 \quad M$. 
Notwithstanding this doctrimal difference berween tort and criminal law, in practice ton sanctions ordinarily are much more certain than criminal sanctions-at least from the perspective of the defendant-because of liability insurance. If liability insurance is available. in nearly eliminates uncertainty in tort sanctions from the perspective of an insured tort defendant. Provided that he or she has purchased adequate liabiliry insurance, the cost $(1)$ the defendant of a tont judgment will always be approximately the same: the opportumity costs of the time spent cooperating in the defense, along with the associated aggravation and inconvenience." Of course, liability: insurance does not entirely eliminate uncertainty from the defendan's perspective. There are other costs to being a tort defendant, and it is always possible that the insurance company will partially recoup the damages paid in the form of higher premiums in the fum Nevrotheless, in practice, liability insurance very substantially reduces uncertainty regarding sanctions, at least from the perspective of potential tort defendants.

In addition to the uncertainty-reducing effect of liability insurance, there are also aspects of tort doctrine that reduce the uncertainty of tort law remedies. For example, in tort law there is an implicit. but very strong. relationship between the objective measurability of categories of tor damages and the degree of difficulty in obtaining those damages. The easiest elements of a tort damages case are the out-of-pocket losses (sometimes called economic losses), such as medical expenses and lost wages. The caregories of damages that are more difficult to calculate, such as pain and suffering or loss of en joyment of life. are more difficult to collect. Indeed. tort law mly grudgingly permitued such "non-ecconomic" damages, and their continued availability is under constant threat from ror reform efforts to place caps on non-economic damages.

82. Hiability insuranse wpicalis covers the costs of defense as well as settement or judgment. Even punitie damages are imsurable in many jurisdirioms. John B. Cartafalsa. Jr..

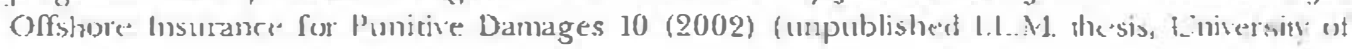

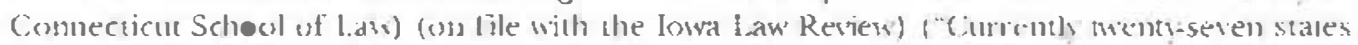
permir reserage. in me way or amolhet. for punitic damages."). So generolly Tom Bakel.

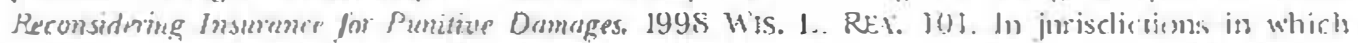
punitive damages are nos insurable. a punitive dumages case is more likeds to settle This practice reduces the uncertainty that is esherwise created by the pullic policy aganst insuranct

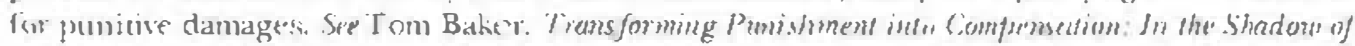

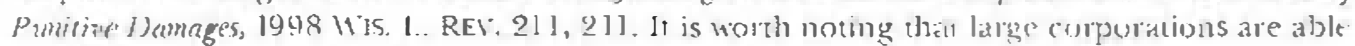

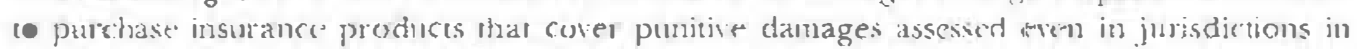

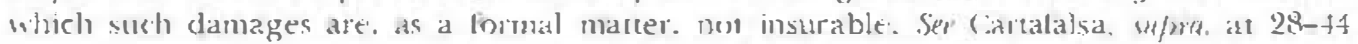

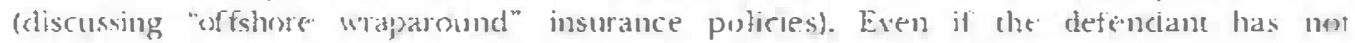
purchased adequate insumaner. the chances that the defendan will be reguired (1) pas ans

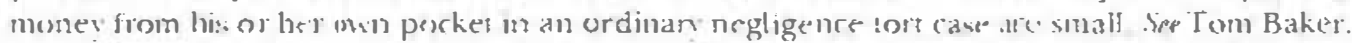

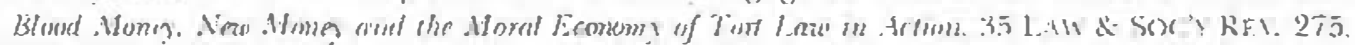

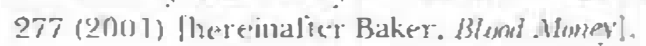

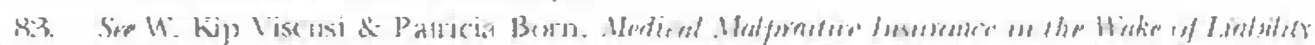

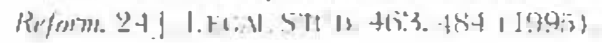


Punitive dambes atre perhaps the mest uncertain of all damages. since: they ane mo neressarils tied (1) the amount of ham inflicted on any particular phatstiff. ${ }^{x t}$ For this teason (among others), punitive damages are a vely comborensal leature of $\mathrm{l}$ S.S. cort law. Features of tort law that reduce the uncertatum regarding punitive damages include frequent decisions by trial courts to remit (i.e., reduce) the amount of punitive damages. In adelition, the propensity for appellate courts to carelisly scrutinize and with some frequenco reverse punizic damages judgments encourages litigants to setule punitive damages case's between thial coml and appeal."

\section{Lincertatinty Regarding the Probability of Detection in Tort I aw}

Outside af courts, tont law does not direcdy address uncertainty with regatd to detection. With the limited exception of statutory torts, there are no public agencies charged with detecting tort law violations (except to the exient that wrt law overlaps with criminal law). Where such public agencies exist, it is our impression that, like criminal justice institutions, their focus is on (increasing) the probability of detection. not the certainty of the probability of cletection. An additional factor compounding the uncertainte of detection in tort baw as compated to crinninal law is that, in contans to criminal law, "attempts" are not actionable in tort. A breach of the relerant lorl law standard is grrounds lon legal action only if that bieach causs:, hatm. In many. perhaps most. cases of negligence (or other civil wrongs). (here is at least some probability that the breach will not cause any hamm, and it serms quite likely that this probability will be uncertain.

\section{Manipulating Uncerrannty in Tom l alw}

Io a degree. the compensation goal of tort law limits the ability to manipulate the certainty with respect to the size of the sanction. On the one hand. the conpensation goal prevents sanctions from being cortain, becatuse tort damages depend on contingenf factors. such ats the chatracteristics of the victim and the nature of the ham caused by the wrongtul behavior. On the oller hand. the compensation goal prevents sanctions from being radically uncertain. once again because the amount of unt damages depends on the hallm.

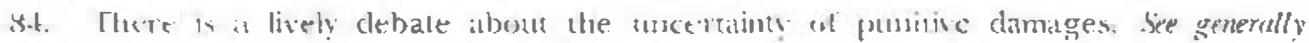

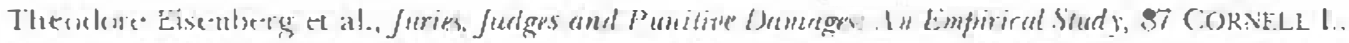

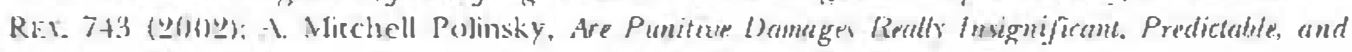

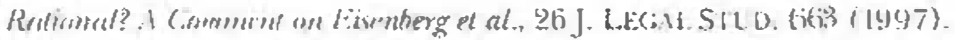

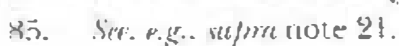

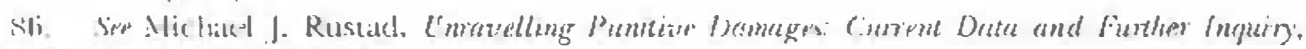
IyYה 11 s. 1.. RF . 15. H (1998)

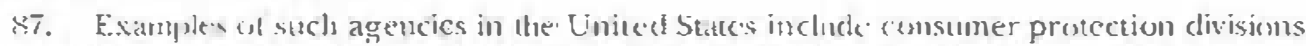

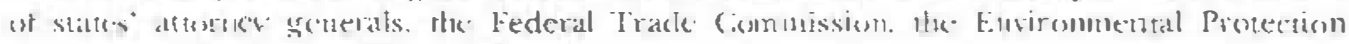

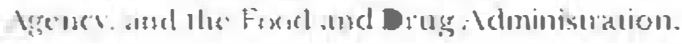


Yet, despite these limitalioms there are mumerous ways by which onc can manipulate centainty in tom damages. One obvious mechanism is punitive damages. In general, punisive damages are imposed to punish defendants. not to compensate victims, so here is no theoretical reason why pumitive damages need bear any particular relationship (o compensatory damages."

Another obvious mechanism is liability insurance. When liabilits: insurance is less available, lort sanctions are more uncertain. For example, a lack of insurance for punitive damages in some jurisdictions makes the practical impact of punitive damages more uncertain, ${ }^{x(9)}$ Similarly, the relative lack of insurance for envirommental harm makes the impact of envirommental liability more uncertain." In addition, the increasingly common practice of excfurlisg coverage for claims relating (o) "criminal acts" turns insumance companies into criminal daw enforcement agencies of a som, and at the same time makes cont sanctions more uncertain in calses involving criminal norms." Finally, closely tying the future costs of liabilit insurance (o) paid tort setilements or judgments (know'n as "experience rating" in the insurance trade) would also increase the uncertainty of tort damages.

Certainty in tort damag(:, may also be affected by rules regarding 100 : damages. Many "ton reform" efforts are aimed at reducing the upper limit of tort damages and. thus, may make tort damages more certain. Examples include restrictions on joint and several liability and caps on mon-eronomic or punitive damages." In addition. the b.S. Supreme Conm is developing comstitutional limits on puntive damages lhat limit the jum siscretion regarding the size of such awads." One of the most impertant implications of our rescarch in the cort aresta is that the reduction in uncertainn resulting from these tort reforms may well magnify the experied hoss in deterrence resulting from dine decline in the amount of damages.

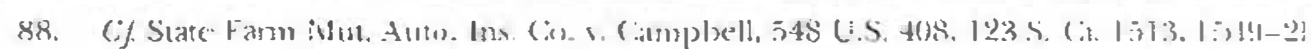

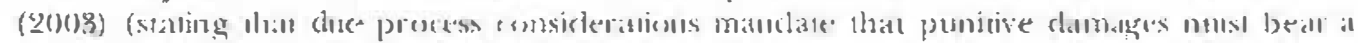

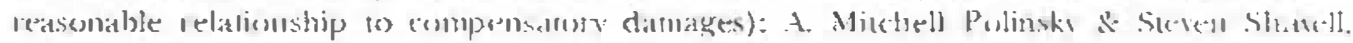

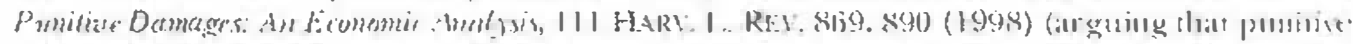

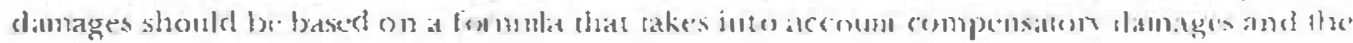

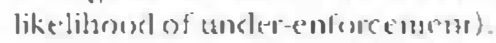

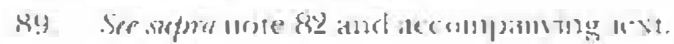

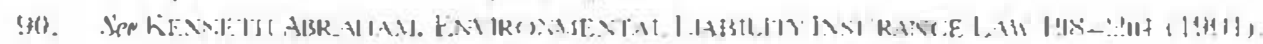

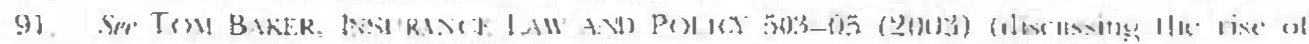

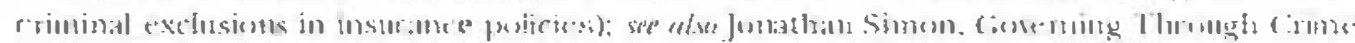

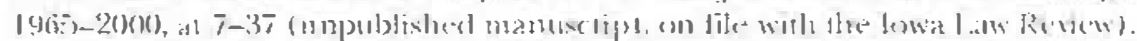

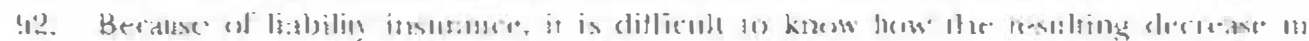

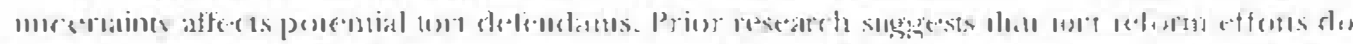

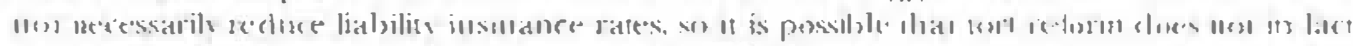

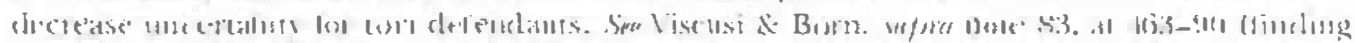

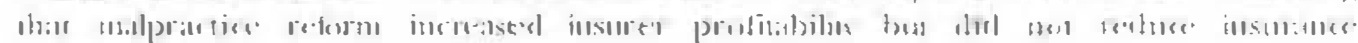
preminns).

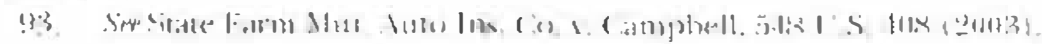


Nanipulating moncertainty in detection is less straightemsand in the tom "rent hath in criminal justice because of the importance of "private" lith entirctment in torts and the lesser role of public agencies. To the extent that public agencies are charged with cutorcing tort and related statutor norms, these agencies should be able to use all of the techniques addressed in the criminal comext above. For cxample, an agency charged with increasing patient salety in hospitals could conduct random, highly intensive atudits of patient records to identify adverse events, many of which would be unlikely (o) ever result in a private tort acton because of historically verv low claiming rates in the medical malpractice arena." W'ith regard to classic ont (baims trought by individual plaintifs, however, there appears to be little that can be done, directly. to manipulits the certainty of detection. Even with concerted efforts by members of the personal injury bar, intensive short-term "enforcement campaigns" seem unlikely to be effective in increasing the uncertainty of detection.

On the other hand, publicity highlighting the "lottery" or "random" nature of tort enforcement may increase the deterrent effects of tort law in fields in which the actual probability of cletection is quite small. Medical malpractice may be one such example. Despite the facts that (1) at very small percentage of adverse medical events result in a medical malpractice claim.: (2) cloctors prevail in the majority of cases that actually go to trial, ${ }^{\text {\%; }}$ (3) medical malpractice insurance is not experience-rated, ${ }^{47}$ and (4) doctors almost never have to pay money out of their own pockets, ${ }^{\text {gx }}$ the threat of malpractice liability allegedly produces a great deal of "defensive medicine." in which doctors perform additional tests and take other precautions to

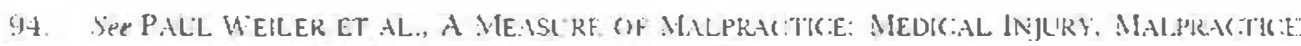

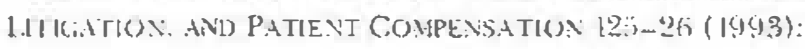

\footnotetext{
Malpractice law seems to function in a manner akin to income tax audits. Only a small fraction of potentially valid malprastice claims ever ripen into lanstuits. Hewever. cloctors' intlated perceptions of the prospect of suit greatly matgify the deterrent leverage that litigation can txert wer medical malpractice, at least by comparison with what would be expected firm a simple calculation of the true statistical risk of suit.
}

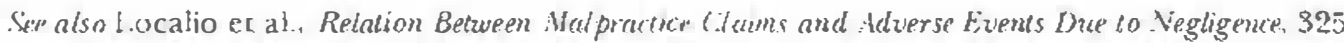
AW Exc: J. ME 245,247 (1991) (reporting th.u fewer than wo percent of negligendy injured patients pursue litigation).

3):. SeQ WEILEK ET .H., supro note 94, at $6 引-7$;

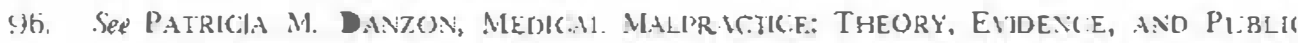
P'sus 38 (1985) (reporting that "plaintitts wim in unly twenty-eight percent" of nedical nalpractice cases tried to verdict).

97. See Frank d. Sloan, Experience Rating: Mim "Make Sense for Medural Malpractice Insurnnce?, til. Ecox. REV.. May 1990. at 128. Experiencs rating is the practice of basing future premitum. in part on the claims history of individual insulteds.

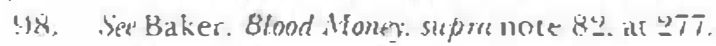


create a farorable record in the everll of a lawsuit. ${ }^{(x)}$ Thus, the medical malpractice arena suggests that uncertainty can be a "force multiplier" and therefore a potentially useful tool in deterring harm, particularly in situations in which it is difficult to increase significantly the average probability of detection.

Environmental enforcement also exploits the deterrent effects of incertainty, though with exactly the opposite combination of certainty and uncertainty in sanctioning and detection. Because of the extensive record keeping and manifest system improsed by the Resource Conservation and Recovery Act (RCRA), hazardous wastes are easily traced back to their source. l"1f If we think of producing the haxardous waste as the "wrong," then the detcetion of that wrong is virually certain for businesses that operate within the law."' What is radically uncertain, however, is the sanction for that wrong. The sanction could be as small as the additional costs of using EPA-approved disposal services, or as great as the costs of cleaning up a future waste site using a very expensive, not-yet-discovered technology.

\section{SIMMARY}

From this brief analysis we reach the following conclusions. First, criminal law has a strong, well-established aspiration, embedded in doctrine. that sanctions should be known in advance. A sinilar, although perhaps less scrongly held, aspiration can also be found in tort law.

Second, despite this aspiration fur certainty in sanctioning, there are ways to manipulate uncertainty. For cxample. in criminal law-the legal field in which certainty may be most cherished-certainty in sanctioning could be manipulated by rejecting the sentencing guidelines or by introducing a larger range of permissible sancioms in llie existing stutencing guidelines. Alernatively, uncertainty could be created by reducing the penalties $f(r)$ altempted (but not completed) crimes, of by borrowing from the victimcentered approach of tort law and increasing the penalsies for completer crimes that cause greater harms. In addition, prosecutors could borrow Rudolph Gutiani s sentencing lontery idea and apply it to decisions on charge up or down, or to decisions about what kinds of plea bargains to entertain. In con law, uncertainty could be increased through efforts directed at

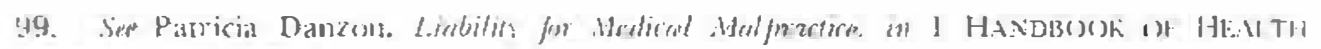
10 (x)

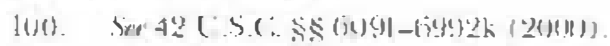

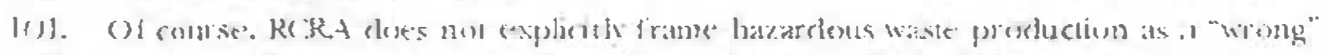

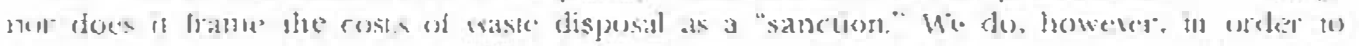

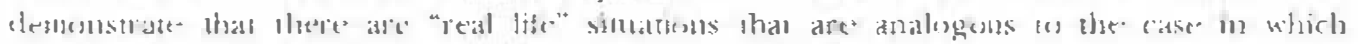

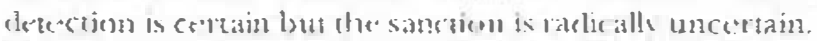

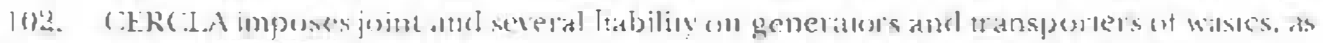

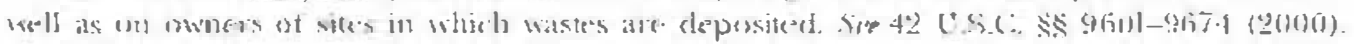

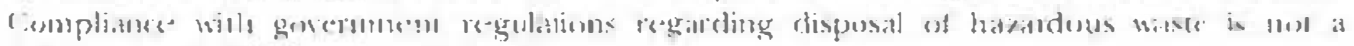

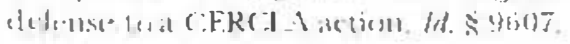


reducing the dampening etfece of liabilits insumance or by efforts directed at increasing the significalice of the less predictable aspects of tomt diunages.

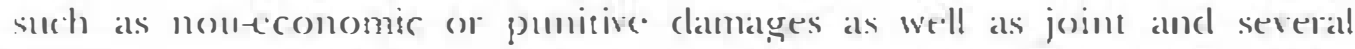
liabilits.

Whether in the end such deliberate attempts to manipulate uncertainty ought to be encouraged in the face of the aspitation for ccrtanty is of course an important question, one to which we do not proposte an allsiver. We propose more modesty that the potential deterrence eftects of uncertainty should be investigated and comsidered-al process that does not seem on have occurred in the contc $x t$ of the heated clebate in the 1970) and 1980s over sentencing guidelines or in the context of the contemporan; beated clebate concerning punitive damages.

Third. while criminal and unt law emborly a strong aspiration for certainty in sanctioning, they do not appear to have the same aspiration for certainty regarding the probability of chetection. This absence is perhaps stronger in tort law han criminal law because tort law enforcement clepends to a greater extent on the decisions of uncorolinated private plantiffs, rather than (at least potentially) corsclinated govermment agencies.

Fourth, given the lack of consistent, principled objection to uncertainty in cletection, cleliberately manipulating that uncertainty ought to be more acceptable. Thus, if uncertains in fact promotes cleserrence. the inclifference of tort and criminal $\mathrm{l}_{a+w}$ un this particulat kind of uncertainn may present an opportunity. Of course. there may be situations in which the probability of detection is already so uncertain that deliberate efforts w increase the uncertainty will have litrle or no effect. Nevertheless. it seems likely that there are other situations in which the probability of cletection is not as uncertain and, therefore, the potential benefits of short term. intensive enforcement campaigns should be considered. Bringing public attention to the relatively high probability of detection during these campaigns, while withholding information about their location and cluration, could bave the effert of expanding the range of uncertainty regarding the probability of cletection.

Finally, this reference (o) public attemeion has an aclelitional important implication. Even if other consiclerations such as famess (for example, in the context of the certaint of the criminal sanction) or practical limits on the abilitg of enforcement agencies in detect wongdoing (in the context of the certainty with respect to the probability of cletection) dictate legal rules and institutional procedures. it is still the case that certainty or uncertatinty could be maniputated to enhance deterrence. This is because it is not certainty or uncertainty per se that produces the deterrent effects of the legal system, but rather beliefs concerning certainty or uncertainty. Thus, by highlighting existing moncertinint-producing aspects of the system (which presumably exist for practical or othes reasons and are not manufactutred in order to increase deterrence), the legal system could enhance deterrence. 
For example, if juries have discretion over the size of pumitive damages becallse of a commitment to democratic ideals, emphasizing the resulting mecertaincy could appropriately and faily be used to promote deterence. even if it would be immoral (o) deliberately introduce the same level of uncertainty into punitive damages solely on deterrence grounds.

\section{OBjLOIONS}

There are at least five significant objections to the suggestion that certainty should be manipulated to increase deterrence: (1) Manipulation of certaing is immoral; (2) Manipulation of certainty is costly; (3) Manipulation of certainty is not effective; (4) Manipulation of certaing is inelficiont because is may lead 10 over/mnder-detertence; and (5) Manipulation of certainty may have unpredictable consequences because subpopulations differ in their aversion to risk. Ve address cach in turn.

\section{A. MORHI CONSWIERAT(MNS}

It could be argued that manipulating certainty, either with respect (o) the size of the sanction of with respect to the probability of detection, is inherenty wrong. It may be wong becanse uncertainty itself is wong or. even if uncertainty is not inherenty wong. creating uncertanty deliberately in order so increase deterence may be wong. The reluctance 10 manipulate certaint? for the sake of increasing deterrence may be founded on one of two moral explanations. It may, for instance, rest on the intuition that such an uncertainty involves differential tratument of people who are similarly: situated and therefore violates principles of equality. "Altematively, is may rest on the beticel that the size of the sanction should reflect the degree of wrong committed and, consequenty. that people who commit the same wongs should be treated in the same way." These wo moral inutions are distinct. ${ }^{\text {thi }}$ The first is gromeded in the icteat of ecquality, while the second is grounded in retributive justice.

These moral intuitions seem particularly compelling when inclividuals who commincd an identical wong uncler identical circumstances receive clifferem sanctions based on a system deliberately stntcumed to promote uncertainly. These intuitions seem less compelling, however, in

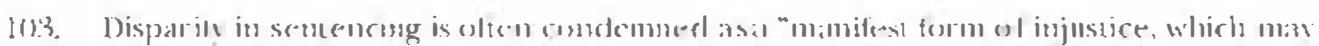

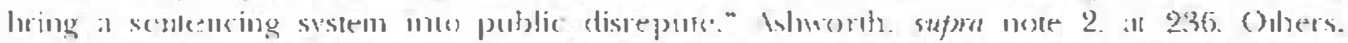

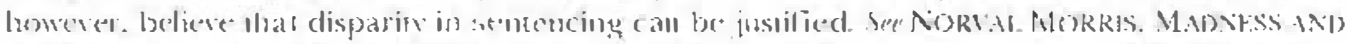

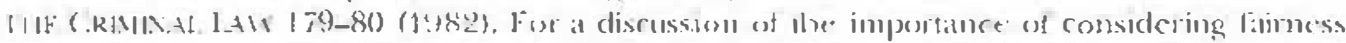
anel cquality in criminal baw. sre. Alum Harel \& (

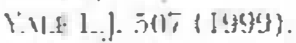

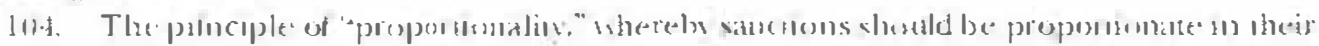

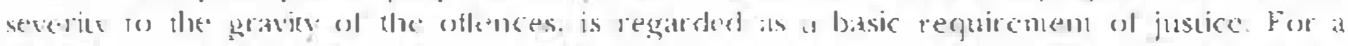

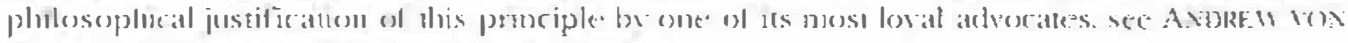

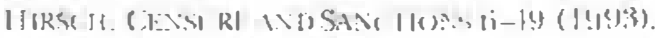

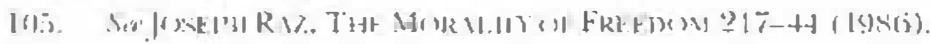


circumstances in which the clisparity is a byproduct of a legal stistem that authorizes legal decision makers on weigh mumerous factors and make a clecision on the basis of an overall juclgment of the culpability or wongfulness of the relevant behavior. in other worcls, there stems to be a substantial difference between (a) a sentence that ranges between five and ten years cletermined by the flip of a dice; and (b) a sentence that ranges between five and ten years according to the discretion of a juclge.

Although both systems lead (o) uncertainty, the former system violates a sense of justice because it is designed to bring about uncertainty and because it also introduces playfulness into the process in which people's fate is determined-a process which is perceived to be one of serious clefiberation. The latter system leads to uncertainty, but it is not clesigned to bring about clisparity in sanctioning; the disparity is simply an unintentional byproduct of a scheme clesigned to take seriously the particularities of ach case. These particularities are so complex that they incritably lead to uncertainty even if this clisparity is grounded in relevant differences between the different cases.

This raises the possibility that existing uncertainty, which is justified on other grounds. conid be emphasized or publicized in order to increase deterrence. without violating moral concerns about cleliberately increasing uncertainty. Some purists may resist this conclusion, however, arguing that, although certainty brought about unimtentionally may be legitimate, uncertainty may never be used to promote cleterrence. In this view. incertainty could be maintained without violating our sense of justice. only if it is not intentionally used to promote cleterrence, but is clesigned for other legitimate purposes.

This concern for certainty secms more compelling with reapers to the size of the criminal or civil sanction than it is with respect to the probatility of cletection. Consequencly, even if one believes that a system which imposes uncertain sanctions is morally abhorrent, one can still approve of generating uncertainty with respect to the probability of cletection for the sake of promoting cleterrence.

Last, it is perhaps worth emphasizing that the ideal of equal sanctions for equal wrongs is not as entrenched as it may seem. Iu his meticulous analysis of legal sanctions, Bentham has argued that: "The last object [of

I0ti. Adnittedly: however, the latter sysem, in which uncertainty is mot designed to enhance dertertence may have less tetertent effects. This is because if the sanction depends on the discretionaty powers of a judge. the oflender may believe he can influence the use of this discretion. The process seems less arbitaty and thus more certain than the arhitraty uss of a coin. Argablify. therefore, innoducing arbitratiness in sancioning presents the policy maker with the following dilemma: Eithe.y uncertainty is inroduced in a way which is blatantly tanjust (such as by cossing a coin), or it is introluced in legitimate ways which have lesser recterrent effects because they aro perceived to be less arbitrary. We are grateful to Buthams Berger for raising this point. 
criminal law] is, whatever mischiel is guarded against, to guard against it at as cheap a rate as possible: therefore the punishment ought in no case to be more than what is necessasy to bring it into conformity with the rules here given." In contemporary literantre, this principle has been labeled the principle of parsimony. The principle of parsimony of ten overrides the puinciple of equatity. ${ }^{\text {IUi }}$ If, by manipulating certainty, the legal system can reduce the average size of the sanction. it follows the dictates of the principle of parsimony-a central principle entrenched in the contemporary legal system.

\section{B. COST}

One could argue that the manipulation of certainty may have its own costs. It is possible, for instance, that conducting enforcement campaigns is more costly than maintaining a consiant degree of enforcement. If the costs of manipulating certainty (either increasing or decreasing it) are high, these costs may override the deterrence-based benefits of such a manipulation. Some methods of manipulating certainty could be costly. Yel, other methods are not. An examination of the overall cosis and benefits of manipulating certainty can be made only after a more thorough investigation of the effects of uncertainty on deterrence. This is precisely what ou experiment is designed to do.

\section{EMTCHZNES}

It may be argued that certainty with respect to the size of the sanction or with respect to the probability of detection are such marginal factors in the decision to violate a legal norm that policies targeted at uncertainty will not be effective. This ineffectiveness objection may be based on an intuitive sense that actors operate on the basis of the expected value of their action and, thus, certaingy plays little role in their calculations. This objection is exactly what our experimem is designed to test.

Alternatively, the ineffectiveness objection may be based on the conviction that the detection of criminal or tortious behavior is already so highly uncertain that the effects of manipulating cortaing further for the sake of increasing deterrence cim al mosi be marginal. This is perhaps the most powerful objection in the analysis provided in this Article. Nevertheless, even witb regard (1) cases in which delection is alleady so uncertain. the analysis is this Article suggests that there mas be law enforcemem benefits to b.' ganed by highlighting this uncertainaty in ordes (1) reap its deterence bentils. Noreover, there undoubsedy are circumstinnces in which the probability of detection at least apperats less

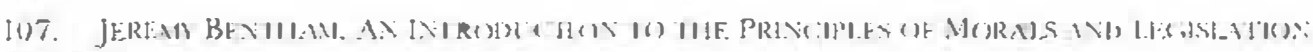
$16 \% 9(1,1)+(1)$.

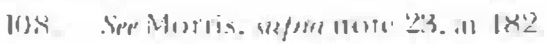


uncertant such as viobations of parking regulations. mattic offensess tax crianes. licealth and saf ety regulations. and the like.

In lixe end, this objection, although vers important, recpuires cletailed empirical reseatrol that is beyond the fimited soope of our project. Whether it is worth conducting that reseatch turns. in signilicant part, on whether uncertaitus can have a cleterent effect. For that question our experiment provicles the begimnings of an answer.

\section{OVTR/UNDIRR-DETTRRRENCE:}

It is sometimes atgued that. if sanctions are othervise set optimally. then uncertainty can cause inefticient ore-compliance. "If uncertaint in fact increases the cleterent effects of some criminal or civil sanctions, then increasing uncertainty would increase the costs associated with committing the crime or wrong. Given the (heroic) assumption that a particular sanction is otherwise set optmally, increasing uncertainty would lead to over-cleterrence. (2n the other hand, with at least some combinations of average sise of sancion and average probability of detection, increasing uncertanty beyond a cortain point may reduce deterrence through a response that may be similat to that of "leaned helplessness" (the term in the psychological literature for the apathy that results when punishments do not appear to be related (s behavior)."1" Thus, clepending on the circumstances, increasing uncertainty could lead to over- or unclercleterrence.

While significant, these concerns do not undercut our analysis. Indeed. they support our effort to investigate the cleterrent effects of uncertainty. If uncertanty infact increases deterrence, then increasing uncertanty maly be a cost-effective way (1) increase deterrence in situations in which there is reason in believe the existing level of cleterrence is not optimal. Aftematively, if existing sancrions are optimal, policymakers may be able $\{0$ reduce the costs of cleterrence by reducing the areange sanction and increasing uncertainty (leading to, for example, lower incarceration costs in the criminal content and smaller average punitive clamages awards in the civil context).

l19. A tinal, less substantial. ineffectiveness objection applies only to repeat plavers in

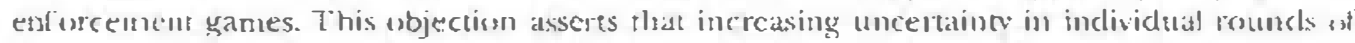
the game will nut change the behavios of peuple whes play of ten enengh so that bhe ir samctiens are based ots the average probability of cietection. If true. this objection would elemonstrate the decerem prower of uncertainty, because the repeat players would be making clecisions from the perspectise of restaingy. rather than uncerlainty. The quintessential repeatt plavers int enforcement games are liahility insurance companices.

1114 Sirecalfee \& Craswell, suprentute 16. al 96.5.

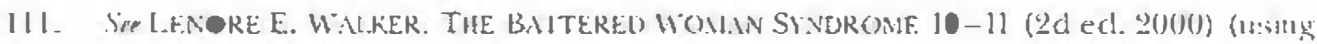
the concept of learned helplessness to explain the battered womar svindrome). See equerally

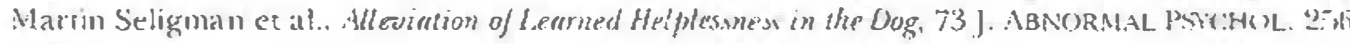
(19isis). 
Polinsky and Shavell have argued that over-deterrence is particularly likely (o) result from uncertains concerning the amoum of the sanction because of the risk bearing cost bone whenever the sanction is set higher than the external costs of the activity that the sanction is intended to discourage." The intuition here is that within the economic analysis of law. the optimal (objective) expected value of a sanction should be set so that it matches the external costs that the activity imposes on society. and that at any time a potential sanction is higher than that amount, the people who "slould" engage in that activity (because their private gains from the activity cxceed the external costs) will be subject to the tisk that they will have to pay a sanction thas exceeds the optimal sanction. Because of risk aversion, the risk of at larger sanction will lead individuals to assign a subjective expected value to the sancrion that will exceed the objective expected value of that same sanction. At the margin, some people who "should" engage in the activity will not, and all people who do engage in the activity will beal a higher risk than they "shoutd." firot this reason, Polinsky and Shavell conclude that, subject to the costs of entorcement, it is more efficient to increase deterrence by increasing the probability of detection than by increasing the size of the sanction."

Although this concesn is also significant, it does mol undercul our analysis. Hnstead, it suggests that in some circumstances there are competing considerations in faver of reducing certain kinds of uncertainn. Moneover; withm their theoretical framework our analysis adds an additional lool to increase deterrence that can be traded off against sancrion sire. namely mancenainty regarding the probability of detection. ${ }^{1 \cdot 1}$

\section{E. VARIATONSINRIKAITRSION}

The fimal olsjection is one that is mon in fact addressed by our (xperiment. This is the objection that increasing uncertainn may have mupredictable results due (o) ststematic variations in the risk aression of subpopulations. For example. there is research that suggests that people in prisons are significantly kess risk-arese on average-and more likely to bo risk-seeking - than undergratuate stuckens.s whe typically pastiripate in behavienal decision research experiments." Thus. if we want as deter at

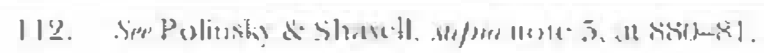

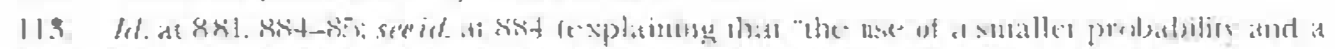

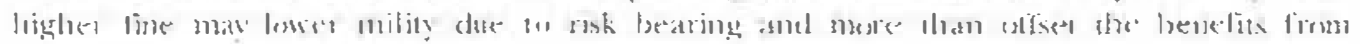

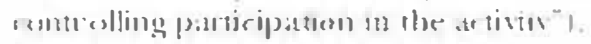

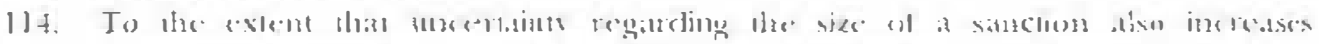

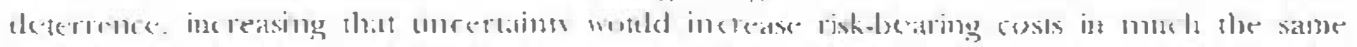

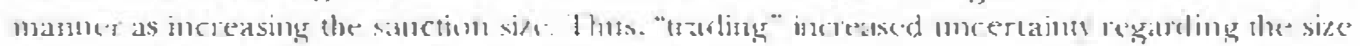

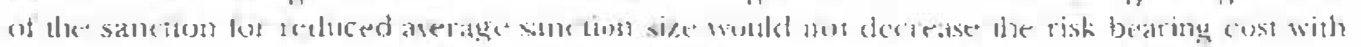

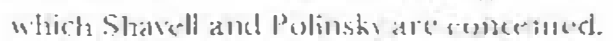

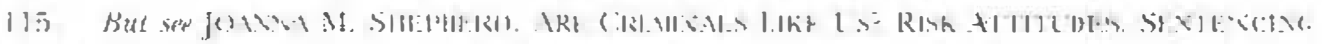

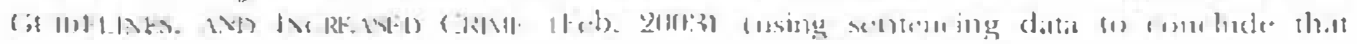


least some kincls of serions criminal activity, increasing uncertainty might be counter-productive. Similarly, therc is research suggesting that the most safety-conscious and law abiding perple might also be the most risk-averse. "in As a result, increasing uncetainty could in some circumstances have the perverse result of over-cleterring those who are abready complying with legal norms while increasing the uncler-deterrence problem among those who are already more castal about complying with legal norms.

It is rerv important to note. however, that this objection can also be raised with regard to efforts to increase cleterrence using the more traditional tools of sanction size and probability. Thus, this objection is not unique to efforts to use uncertainty to increase deterrence. Accordingly, although variations in aversion to uncertainty are important and worthy of further investigation, that investigation is worth pursuing only if one is lirst persuaded of the potential deterrent effects of uncertainty. That. of course. was the primary object of this research.

\section{CONCLUSION}

Traditionally. legal scholarship in criminal law and in tort law has forcused attention on the amount of and the procedure for determining sanctions. Law and economics analysis expanded that traditional focus by clemonstrating the importance of considering the probabilin of cletection and rish aversion. As that andysis has demonstrated, it is the expected sunction that matters, not the absolute size of the sanction. Indeed, higher sanctions could in some circunstances lead to a lower probability of detection, with a reșulting clecrease in cleterrence, and vice versa.

lising the insights of behavional decision research, this Article has cmphasized yet another factor that aftects the deterrence value of civil and

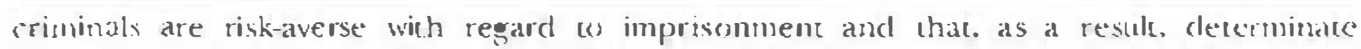
sentencing increases crime), available at hrtp://papers.ssnn.com/solla/dclivers.ctm/

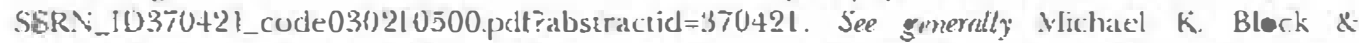

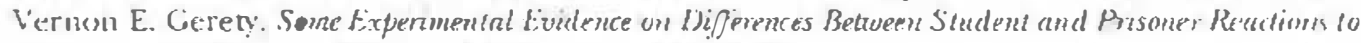

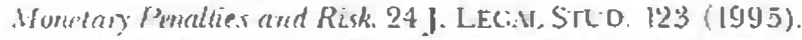

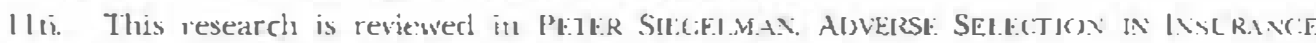

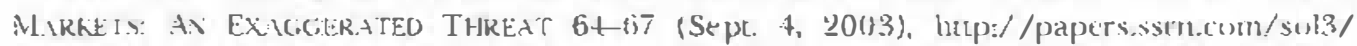

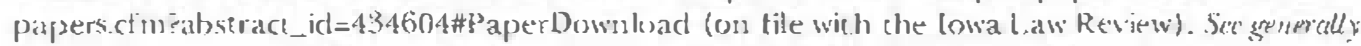

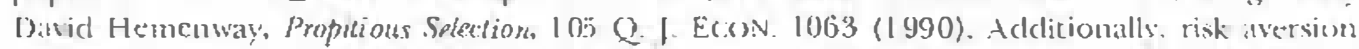
has heen suggested to vary by eccupation, emirumental facuors, and culture. fire D. T. Eiceles

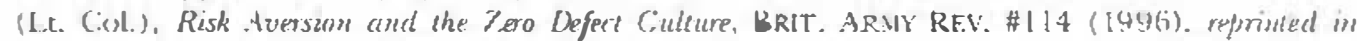
News:kax.com. Nov, 14, 1998 (discussing four trends of risk aversien among (1.S. snldiers inder the war-stiessed circumstances of Busmia during the mid-1990s). at hetp:/iwns. newsmax.com/articles/print.shml?a=1998/11/14/8163\%; Jesseph Henrich \& Rirhard

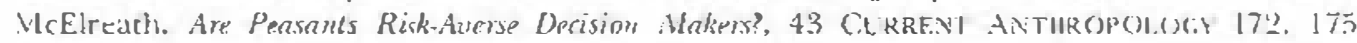
(20)(r) (discussing the strength of culute as a facter in determining risk atrersion); Richatrd

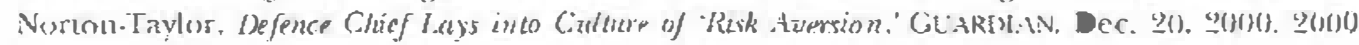
WL. 3081:3529 (warning of the prospect of voung officers being sued bs their platusts fios

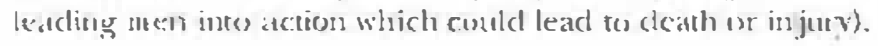


criminal sanctions. It is not only the expected sanction that coumts, but also the certainty with which that expected sanction can be known in the individual case. Varying the cestainty of the size of the sanction or of the probability that it will be imposed also affects the deterrence value of the sanctioning system.

The conclusions drawn from our research and analysis are likely to depend, at least in part, on perspective. Staunch believers in law and economics may conclude that legal thinkers should rethink their uaditional hostility towards uncertainty. Other legal scholass may conclude that this Anicle provides yet another demonstration that legal institutions do not rest on economic rationales. Perhaps the most reasonable conclusion to draw, however, is that in contexts that do not raise serious concerns of injustice and unfaimess. uncertainty could indeed be manipulated in order 10 increase deterrence without compromising the ideals underlying legal institutions. 